\title{
WestVirginiaUniversity
}

THE RESEARCH REPOSITORY @ WVU

Graduate Theses, Dissertations, and Problem Reports

2006

\section{A hairy predicament: The problem with long hair in the 1960s and 1970s}

Andrew Robert Herrick

West Virginia University

Follow this and additional works at: https://researchrepository.wvu.edu/etd

\section{Recommended Citation}

Herrick, Andrew Robert, "A hairy predicament: The problem with long hair in the 1960s and 1970s" (2006). Graduate Theses, Dissertations, and Problem Reports. 872.

https://researchrepository.wvu.edu/etd/872

This Thesis is protected by copyright and/or related rights. It has been brought to you by the The Research Repository @ WVU with permission from the rights-holder(s). You are free to use this Thesis in any way that is permitted by the copyright and related rights legislation that applies to your use. For other uses you must obtain permission from the rights-holder(s) directly, unless additional rights are indicated by a Creative Commons license in the record and/ or on the work itself. This Thesis has been accepted for inclusion in WVU Graduate Theses, Dissertations, and Problem Reports collection by an authorized administrator of The Research Repository @ WVU. For more information, please contact researchrepository@mail.wvu.edu. 
A Hairy Predicament: The Problem with Long Hair in the 1960s and $\underline{1970 s}$

\author{
Andrew Robert Herrick \\ Thesis Submitted to the \\ Eberly College of Arts and Sciences at \\ West Virginia University \\ in partial fulfillment of the requirements for the \\ degree of
}

\author{
Master of Arts \\ In \\ History
}

\author{
Elizabeth Fones-Wolf, Ph.D., Chair \\ Kenneth Fones-Wolf, Ph.D. \\ Steve Zdatny, Ph.D. \\ Department of History \\ Morgantown, WV \\ 2006
}




\begin{abstract}
$\underline{\text { Abstract }}$
A Hairy Predicament: The Problem with Long Hair in the 1960s and 1970s
\end{abstract}

Andrew R. Herrick

By the mid-1970s long hair worn by much of the American youth evoked little comment and indeed was considered fashionable. But during much of the previous two decades male hair length was a contentious issue that divided the generations. The struggle over hair in many ways epitomized the sixties generation's challenge to authority and their claim to individual rights. During the era, the meaning of long hair changed dramatically from what it was during the fifties. It began as a symbol of youth culture rebellion linked to music. By the latter part of the sixties, however, it became associated with a political and social critique of American society. Quickly, hair length, like bell bottoms and other symbols of youth rebellion became commercialized and meaningless. This paper focuses on the conflict over long hair at educational institutions, in the workplace, including both the military and the traditional workplace, and within popular culture. Finally, a short look at its effect on the barbering industry. 
$\underline{\text { Table of Contents }}$

Introduction: The Long and Winding Road: The Beginnings of the Long Hair Controversy

1. Hello, Goodbye: High School Students and Suspensions over Long Hair

2. Working Class Hero: The Workplace and Problems with Hair Length

3. Across the Universe: How Popular Culture Helped to Lengthen Hair 


\section{The Long and Winding Road: The Beginnings of the Long Hair Controversy}

By the mid-1970s long hair worn by much of the American youth evoked little comment and indeed was considered fashionable. But during much of the previous two decades male hair length was a contentious issue that divided the generations. The struggle over hair in many ways epitomized the sixties generation's challenge to authority and their claim to individual rights. During the era, the meaning of long hair changed dramatically from what it was during the fifties. It began as a symbol of youth culture rebellion linked to music. By the latter part of the sixties, however, it became associated with a political and social critique of American society. Quickly, hair length, like bell bottoms and other symbols of youth rebellion became commercialized and meaningless. Thomas Frank notes that advertisers began co-opting values of the "cool" counterculture and made them their own. At the Atlanta Pop Festival in 1969, Janis Joplin saw the change from subculture to mass culture. "Like, two years ago you could walk down the street and see a guy who looked real weird... and you knew. Now, I look out here and, well, everyone looks weird. You just can’t tell anymore."1

Hair touches on a variety of historical themes and literatures, particularly the history of youth culture and music. Youthful challenges to authority were not unique to the sixties. The Bible recognized that often sharp disagreements existed across generations characterizing one as "a stubborn and rebellious generation.",2 Eighteenth century German poet, novelist, playwright, and philosopher Johann Wolfgang von Goethe once said in reference to the new generation that they felt "the world began with them." During the Reformation zealous youths were important for their commitment to

\footnotetext{
1 "Marietta Long Hairs," Great Speckled Bird, 20 September 1971, pp. 4-5.

${ }^{2}$ Psalms 78:8, 622.
} 
spreading the new gospel. Historians have noted the youthfulness of the men who created the American Revolution. ${ }^{3}$ In England during the 1830s, youth played critical roles in such popular uprisings as the Swing Rebellion and the Rebecca Riots. ${ }^{4}$

The first half of the twentieth century saw the expansion of the youthful malaise that began in the nineteenth century.

The disenchantment of Bohemian garrets spread broadcast among the sons and daughters of the bourgeoisie. The revolutionary political and social doctrines nurtured by radical European youth spread beyond the confines of Europe, to find new generations of converts in Asia and Africa and the Americas. In the twentieth century, in short, the youth movement became a mass movement. ${ }^{5}$

The youth of the 1920s created a culture of rebellion. Their main agenda was not political or economic change. They dove into the new world of jazz and bathtub gin. As with bobbed hair and short skirts, the twenties also saw distinctive hair and fashion associated with a youth movement. They shocked their parents with their "hedonistic escapism and their moral anarchism." As Paula Fass understood it, "The youth of the twenties were at once the product of change and the agents of change, because they existed at a strategic point in history when their actions really did make a difference." ${ }^{7}$ Faced with the Great Depression, the thirties were also a time for youth oriented movements. The difference was that they turned once more to social and political commitment. The youthful involvement in the anti-war movement during the thirties and

\footnotetext{
${ }^{3}$ Anthony Esler, Bombs Beards and Barricades: 150 Years of Youth in Revolt (New York, N.Y.: Stein and Day Publishers, 1971), p. 34.

${ }^{4}$ Schools History, 11 July 2004, $<$ http://www.schoolshistory.org.uk/> (22 March 2005).

${ }^{5}$ Esler, "Bombs Beards," p. 38.

${ }^{6}$ Ibid.

${ }^{7}$ Paula S. Fass, The Damned and the Beautiful: American Youth in the 1920s (New York, N.Y.: Oxford University Press, 1977), p. 5.
} 
the youthful fascination with zoot suits during the forties were both precursors to events and attitudes that developed during the sixties generation.

Any sort of historical trend or traumatic event can leave its mark on a generation. Every generation has one. This may include political or military events, economic developments, or changes in value systems. As Anthony Esler observes, "A generation of young people is stimulated intellectually and emotionally by an unusual twist of history. A war, a depression, a major reform movement launched by their elders - almost any sort of political upheaval may provide a spark." 8 This has never been seen more clearly than in the 1960s. Where the 1920s saw Prohibition and women's suffrage and the 1930 s were ravaged by the Great Depression, the sixties had a combination of many of the historical trends and traumas. The sixties saw the conflict in Vietnam and the civil rights movement. Indeed at the forefront of people's minds was the idea of individual rights. This was expressed emphatically by the women, civil rights, student, and gay rights movements.

It was not like those events suddenly appeared in the sixties. The feminist movement was rooted in the women's suffrage movement of the nineteenth and early twentieth centuries and reemerged as a major force in the sixties. ${ }^{9}$ Economic recessions were not new things either. They occur every ten years or so throughout American history, not to mention the Great Depression of the 1930s. War is almost seen as a staple throughout the history of the nation. Founded in revolution, America has perpetually been involved in war. The nation had just gotten out of Korea and many historians see World War II as simply the beginning of the Cold War, which is why America entered

\footnotetext{
${ }^{8}$ Esler, "Bombs Beards," p. 31, 33.

${ }^{9}$ John C. McWilliams, The 1960s Cultural Revolution (Westport, C.T.: Greenwood Press, 2000), p. 9.
} 
Vietnam. These were not new experiences for the nation in the 1960s, but in terms of change and revolution it was as if the stars were aligned. It was the first time that all these events were occurring simultaneously.

The fifties saw dramatic changes in popular music with the rise of rock and roll. Early rock, although dramatically different in context of message to rock of the late sixties and early seventies in that political and social critiques of society were not prevalent in the lyrics, was subversive music. It grew directly out of African American rhythm and blues and was infused with African American music and attitude, but it was marketed to white teenagers. "The sexual innuendoes, the aura of defiance toward social norms and the raw emotional voltage of the music sent a very different message to fifties teens than did the standard popular music aimed at white audiences. ${ }^{, 10}$ Others feared that rock would break down the prejudices of white America that separated the races. Adults in the fifties saw rock as a cause of juvenile delinquency and even as a communist plot to undermine Americans' morality in teens. ${ }^{11}$ Suggestive lyrics and the sexuality of musicians like Elvis challenged the morals of 1950s society: "The second half of the [fifties] witnessed a strange national anti-rock and roll frenzy, a mixture of racial, generational, and professional fears. As the concern over obscene lyrics subsided in 1955 , the attack shifted its focus to the raucous live concerts, with racially mixed performers and audiences. The music obviously encouraged young people to start dancing in the aisles and crowding the stage..."12 Fifties rock also saw the beginning of a phenomenon that has lasted until today. Jerry Lee Lewis and Elvis Presley's unique

\footnotetext{
${ }^{10}$ Dominick Cavallo, A Fiction of the Past: The Sixties in American History. (New York, N.Y.: Palgrave, 1999), p. 150.

${ }^{11}$ Ibid.

${ }^{12}$ Ronald D. Cohen, “The Delinquents: Censorship and Youth Culture in Recent U.S. History," History of Education Quarterly 37 (Autumn, 1997), pp. 251-270.
} 
style, which is most commonly associated with slicked back hair known as the greaser look, permeated its way into the youth culture. Young boys who listened to the music wanted to emulate their idols and the greaser look became popular across America.

In the early to mid sixties, the Beatles began to popularize a new look associated with rock and roll. Shaggy hair that grew to just over the tops of the ears became the standard among musicians. In the spring of 1964 the Beatles entered American airspace and for the first time stepped out of the airplane to a mob of screaming fans. Little did they know that at that moment they would not only become the most influential band in the history of rock music, but that they would ignite a cultural controversy with their moptops that was to last the rest of the decade and into the next. John Lennon, Paul McCartney, George Harrison, and Ringo Starr (a.k.a. Richard Starkey) stepped off the airplane and immediately received questions and comments on their hair. One reporter asked whether or not they would be getting hair cuts anytime soon. Harrison responded, "I just had one yesterday." were about bring to the United States and called their long hair a "British phenomenon." Within months of the British invasion, male moptops began to spread and by the spring of 1965 the crew cut was dying. What began as the youngest teen followers of rock groups had spread across America to many of the youth generation. Bill Severn reported, "A Chicago barber found eighty percent of his young customers asking for long cuts...According to an oarsman at Eastern College, 'Not even members of crew have crew cuts. ${ }^{\prime 14}$

\footnotetext{
${ }^{13}$ ABC, "The Beatles Anthology," 31 August 1996.

${ }^{14}$ Bill Severn, The Long and Short of It: Five Thousand Years of Fun and Fury over Hair. (New York, N.Y.: David McKay Company, Inc., 1971), pp. 1-2.
} 
What had begun in the fifties as a moral debate over rock and roll had become a political and social debate by the sixties. The anti-war and counterculture movements were the prevailing factor in the rock of the sixties. Into the sixties and seventies adults continued to denounce rock music. All they comprehended was that musicians were exposing their genitalia (Jim Morrison at a concert in Miami), dosing horses with LSD before rides (Mickey Hart of the Grateful Dead), and coming to concerts with cocaine dangling from their nostrils (Neil Young). They did not see the work ethic of musicians or the inspiration to the youth. ${ }^{15}$ Rock and roll was the most pervasive feature of youth culture. Millions of fans were drawn to the music as some were seeking to liberate themselves from what they saw as a repressive society. Rock and roll was a driving force behind many social changes. As long hair became more and more associated with rock and roll culture, it also became more and more unacceptable to many adults.

The initial cultural rebellion linked to music became wrapped into a broader youth rebellion associated with the student movement, anti-war movement, and ultimately the counterculture which involved sex, drugs, and the rejection of capitalism. The sixties was the time when members of the baby boom generation were entering their teens. The largest section of the population was at a time in their lives when rebellion was at their fingertips. They were asserting themselves through various forms. Whether it was as hippie, a member of the New Left, or a participant in the anti-war movement, many young people involved themselves as much as possible.

Drugs as a part of youth culture in the sixties cannot be overlooked. Henry Bill, head of the American Medical Association's committee on drug dependency, estimated that the number of illicit drug users rose from a few hundred thousand at the beginning of

\footnotetext{
${ }^{15}$ Cavallo, "Fiction of the Past," p. 146.
} 
the decade to over 8 million by $1970 .{ }^{16}$ The media publicized the links between the counterculture and drug users. ${ }^{17}$ To many Americans, every member of the counterculture engaged in antisocial behavior. Any young person, who became involved in any sort of rebellion, whether it was as a hippie or a dove, was associated with the drug use and antisocial behavior of the counterculture. Because they were young and all wore bellbottoms and the boys wore their hair long, it was easy to lump everyone together:

"For many Americans by 1967, antiwar demonstrators were not only unruly and potentially violent, but hippies, whose life-style was even more threatening and a greater offense to middle-class sensibilities than was their advocacy of leftwing political causes. Thus, because of what they wore and the people with whom they hung out, serious politically oriented activists became easily conflated with hippies to the detriment of their cause." 18

The media focused on more radical events in order to gain viewers or readers. This led the nation to believe most youth were involved in antisocial behavior. Melvin Small maintains that the media generally does not look favorably upon any movement that resists official policy. While reporters and journalists may be liberal or even moderate, their bosses tend to be conservative when it comes to disorder in society. Small presents five factors that lead the media to defend the status quo: their size and wealth, the role of advertising, their reliance upon government and other elite officials for information, the government's ability to pressure them, and an anticommunist, pro-capitalist bias.

\footnotetext{
${ }^{16}$ John C. McWilliams, The 1960s Cultural Revolution, p. 17, as cited by William Manchester, The Glory and the Dream: A Narrative History of America, 1930-1972 (New York, N.Y.: Bantam Books, 1974), p. 1114.

${ }^{17}$ McWilliams, "Cultural Revolution,” p. 17.

${ }^{18}$ Melvin Small, Antiwarriors: The Vietnam War and the Battle for America's Hearts and Minds. (Wilmington: A Scholarly Resources Inc, 2002), p. 79-81.
} 
Therefore, any demonstrations run mostly by antiestablishment young people would not have received positive treatment by the media in the sixties. ${ }^{19}$

The sixties youth had the experience of an intense period of rebellion. All the factors that have historically been attributed to youth insurgence were present and stronger than any period in the past. Cultural revolution like in the twenties and political and social revolutions like the ones that were present in the thirties, all occurred in a single decade.

Authority figures, including parents, teachers, and employers viewed long hair in a variety of different ways. One point of view involved a concern about the loss of masculinity and a challenge to gender roles. Many saw boys with long hair as effeminate and homosexual. Because of the connection most of America made between hair length and the counterculture, long hair became a symbol of drugs and free love. These assumptions and fears represented a basic critique of American society. Parents worried about problem drinking, drug-use, pregnancy, and violence. The common connection seemed to be hair. To them, long hair resulted in dropping out, quitting school, quitting work, and completely dropping out of society.

Struggles over hair occurred in almost every realm of American society. Long hair also had an economic impact on the barbering industry. Chapters of this thesis will focus on the conflict in schools, workplaces, and the military and explore the economic consequences of changing hair styles. Chapter 1 will focus on the conflict over long hair at educational institutions. While many of the youth-led revolts were focused at the college level, the long hair issue was not. Other than in college athletics, hair was never a

\footnotetext{
${ }^{19}$ Melvin Small, Covering Dissent: The Media and the Anti-Vietnam War Movement. (New Brunswick: Rutgers University Press, 1994), p. 13.
} 
concern on college campuses. The struggle took place in public high schools.

Expulsions, suspensions, and many city-wide debates over hair were part of everyday life in high schools. Chapter 2 will look at youth culture, but from a different perspective. Long hair in the workplace, broadly defined here to include both the military and the traditional workplace, was just as contentious as in high schools. During the Vietnam War era military discipline eroded as soldiers both overseas and in the U.S. increasingly refused to comply with regulations including rules about hair length. Expressions of individuality were countered with court martials and even bans from bases. Similarly young long-haired workers, many Vietnam War veterans, challenged the authority of their employers and union leaders. Chapter 3 explores the intersection of popular culture and long hair. Musicians, athletes, and movie stars influenced an entire generation of young people as many stars were emulated and imitated across the country. Chapter 4 takes the issue and turns it on its head. How did this continued growth of hair affect the group that requires cutting men's hair to make a living? Barbers felt the economic impact of changing hair styles. Barbers not only lost money from not cutting hair, but many did not have the skills to style long hair the way men desired. Men began going to stylists, and barbers had to learn to how to become both barbers and stylists at the same time.

In the 1960s, hair was contentious. From schools and town hall meetings to the military, debates over hair touched on people's everyday lives. Much has been made of the unrest during the 1960s. It was after all a turbulent time for the nation and our nation's youths. But this thesis's focus is not the specific cultural events that changed the decade; it is the symbolic gestures that led a generation to express their individual rights 
and the rights of others. Long hair became such a symbol. It scared adults and challenged the very conformist authority that the youth was fighting from the beginning. An account of the incidents that occurred because of this challenge reflects the hostility and torment many young people faced for expressing their beliefs. Young men growing their hair long did not cure our society of the problems that plagued it. Others, whether they were long or short haired, were on the front lines of clashes fighting to make the world a better place. They helped to cure some of the ills in our society. Long hair unified a generation and became a symbol of the fight against authority to make a better United States. 


\section{Hello, Goodbye: High School Students and Suspensions over Long Hair}

“We can't mold people who are going to run the world in the 1980s into the shapes of the 1920s...We just can't expect to make the future look like the past. It's bad education even to suggest it." ${ }^{20}$ This was the response of U.S. District Court Judge James B. Parsons in Chicago in the fall of 1969 which ordered Barrington Consolidated High School to readmit two students who were suspended for wearing their hair too long. This was not just an isolated incident. From the mid-sixties up until the early seventies, thousands of incidents like these plagued the high school education system. Fights over long hair and beards, short skirts, and bellbottoms became commonplace in everyday society, but long hair became the major point of contention. Through these battles students fought to express and in some cases gain their rights as individuals. As a result, the High School Bill of Rights was established in many schools.

So the question becomes whether young people were simply growing their hair long out of spite and disrespect for adults or whether there was a greater cultural aspect to it all. Students were not just growing their hair to anger their parents and principals, but to express their individuality, an idea that has shown itself among youth throughout history. So what makes the long hair controversy of the sixties different from any other youth revolt throughout history? It was a combination of things. The sixties did not challenge authority, the youth of the sixties did. Everything that was happening in the sixties accelerated and expanded youth movements. Hair, while being a small part of the sixties revolution, became the unifying symbol and was therefore greeted with hostility and misinterpretation. Along with a greater understanding of why students were growing

\footnotetext{
20 “Long and Short of It,” Newsweek, September 1969, pg. 77.
} 
their hair long, this chapter will also explore the reaction of adults to a youth culture that seemed to threaten their basic values.

Long hair became a symbol of the decade of youth rebellion. For the youth of the United States, long hair was independence and it was a statement. This representation of the times is seen very clearly in the musical entitled Hair. First opened on October 17, 1967, Hair, the first rock musical, was a concept musical reflecting the anti-establishment energy of 1960s American youth culture. Gerome Ragni and James Rado, the two coauthors, were fascinated by the 1960s youth culture and began to do field research in New York City. They interviewed and documented the lifestyles of hippies who had rejected dominant social mores and values, choosing instead to fight for abstract principles like freedom, justice, and liberty. The authors found that these youth held decided opposition to American military involvement in Vietnam, demonstrated a fondness for marijuana and other experimental drugs, cherished a newfound sense of sexual freedom, and positioned themselves firmly against environmental destruction, racial segregation, and religious dogma. For the first time on the mainstream stage, audiences witnessed drug use, explicit language, an openly gay character, and drag queens. ${ }^{21}$

Just as in Hair the musical, long hair became the symbol of youth culture across the United States by the mid-1960s. Long hair was becoming more and more controversial across the country. Parents and authority figures found it threatening because of its association with drug use and antisocial behavior and because of its skewing of gender lines. Indeed police often targeted long haired youth. A New Jersey

\footnotetext{
${ }^{21}$ Jason King, St. James Encyclopedia of Pop Culture, 2002,

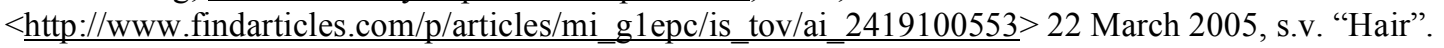


prosecutor ordered the police in Medford, New Jersey, to refrain from harassing longhaired youths by stopping and searching their cars without cause. The Public Safety Director maintained that the police had only stopped cars for traffic violations. The New Jersey ACLU threatened court action to prevent the police from stopping and searching cars in the absence of violations. ${ }^{22}$ The ACLU eventually filed a suit on behalf of thirtyseven plaintiffs who were stopped and searched over a period of two years. They charged that their Fourth Amendment protection against illegal search had been violated. The plaintiffs went on to allege that State Police harassment was so common that New Jersey had earned a national and international reputation as a place to avoid if a traveler had long hair. A British travel guide even warned young Englishmen with long hair to stay away from the Turnpike if they planned to travel between New York and Philadelphia. ${ }^{23}$

Another incident occurred later that year in New Jersey that involved the authorities. In December of 1970, the New Jersey State Police were charged with pursuing a systematic policy of illegally searching longhaired people on the New Jersey Turnpike. Stephen M. Nagler, the director of the ACLU in New Jersey, said, "the Fourth Amendment doesn't exist on the New Jersey Turnpike," and that the current State Police policy of searching cars "was encouraging a disrespect for the law." A State Police commander responded, “There's so much long hair on the highway now that we'd spend all day combing our way through it and we'd have no time for anything else." Among the thirty-seven plaintiffs were four lawyers, eight law students, several teachers, and

\footnotetext{
22 "Jersey Police Told to Stop Harassing Youths in Cars," New York Times, 2 August 1970, sec. 1, p. 60.

23 “Jersey Is Said to Harass Long-Haired," New York Times, 22 December 1970, sec. 3, p. 25.
} 
number of college students. Of the thirty-seven, only ten were arrested. ${ }^{24}$ The State Court ruled that the state police did not have the right to stop and search the car simply because the occupant had long hair. The Appellate Division of the Superior Court ordered that the evidence seized in the searches be suppressed, specifically, an aspirin bottle that allegedly contained both narcotic and prescription drugs. The court's ruling stated:

It is apparent that the officer stopped the defendants and ultimately searched their vehicle because he did not like their appearance - particularly long hair and beards. There is nothing under the law of this state, as far as we know, which makes the wearing of long hair and /or a beard a criminal activity. State Police officers are commissioned to uphold the law....They do not enforce their own personal likes and dislikes. ${ }^{25}$

Similarly, an English graduate student who was touring the United States for the summer was forced to cut his hair in California because he was tired of being stopped and frisked by local law enforcers. The student responded that "[His hair] wasn't really all that long, but the hostility was so great in some parts of the country that I was afraid of something even more serious happening." ${ }^{26}$ In Key West, Florida, the twenty-one year old cousin of Prime Minister Pierre Elliott Trudeau of Canada, Cerje Trudeau, was charged that he rode a bicycle without a light. According to Cerje, "This would never have happened if I didn't have long hair.” Apparently the Prime Minister also wore his hair long. $^{27}$

\footnotetext{
${ }^{24}$ Ibid.

25 “Suspects' Search Is Ruled Illegal," New York Times, 13 July 1971, pg. 29.

${ }^{26}$ Joan Cook, "In the 60's, Hair Was a Fighting Word," New York Times, 31 December 1969, sec. 1, p. 29.

${ }^{27}$ James F. Clarity, "Notes on People," New York Times, 1 June 1972, p. 32.
} 
It was not just long hair that caused problems for travelers, but appearance in general. One man wrote to the New York Times about a trip he took to Montreal. On his way home, this "honest citizen of the United States" and a disabled veteran with a beard was stopped and his bags were searched not once, but twice at Laguardia Airport. His person was searched as well. He claimed that only three people were stopped on the entire flight, all three had long either long hair or a beard, and all three had their bags searched at least twice. Officials of the Customs Bureau in Washington declined to respond to the letter, but a spokesman said, "We are engaged in a nationwide crackdown on narcotics, and unfortunately many innocent travelers face some inconveniences. However, the idea that people with long hair are being picked upon for special treatment is nonsense. ${ }^{, 28}$

Many municipalities began to adopt Puritan-type laws in order to keep longhairs in check and out of their town. Carmel, California made sleeping on the grass and digging up the beach illegal as part of their more stringent control on behavior in public. Similarly in Swedesboro, New Jersey, kissing, hugging, and all types of "improper or indecent action" in its Narraticon Park were classified as crimes punishable by fines up to \$200. Some of the new package of laws enacted in Caramel are conventional and include the destruction of public property. Others, however, are more unconventional and include tree climbing. Hugh Bayless, the city administrator for Caramel, said that public property was being "abused" by "undesirable and unsanitary" visitors. The situation grew to a point where the new laws went into effect immediately under a declaration of emergency rather than after the customary 30-day waiting period. According to Bayless,

\footnotetext{
${ }^{28}$ Donald Knoob, “Letters: Beards, Bags and Customs,” New York Times, 20 September 1970, sec. 4, p. 76.
} 
the laws were "quite an effective deterrent." Liberal critics of the new ordinances said that they are aimed at longhaired, unkempt persons who personify the hippie stereotype. Ernest Besig, executive director of the ACLU office in San Francisco, said that the laws directed at the unkempt and unshod are "unreasonable and arbitrary." He concluded, "We're talking about minority rights. There's just no rational reason to discriminate against people who have long hair."29

When one thinks of many of the movements and controversies in which the youth were involved in the sixties, activism on the college level comes to mind. But young people in college were not in any danger of being expelled for wearing long hair. This is in large part because there was already more freedom at this level, and most professors tended to be more liberal. College students did deal with the long hair issue, just not in the same way as high school students. In 1968 the Haverford College tennis coach resigned because the college refused to order his players to cut their hair. Coach Bramall said, "Long hair, beards, and mustaches did not belong on the tennis court." The thought of hippie-looking players repulsed him. ${ }^{30}$ Football coach Frank Navarro of Columbia said of long hair, "We don't have time to grow long hair, to be sidetracked. We're playing football, we're concentrating. Long hair and beards lead to other things, to lying under trees and singing songs. ${ }^{, 31}$ The stereotypes were deep in society, even at the more liberal college level. Even though college students did not have the same problems with wearing long hair, when the problem arose they acted. On March 23, 1967, twelve

\footnotetext{
${ }^{29}$ Norman Sklarewitz, "Unwelcome Visitors: Some Towns Legislate Against Hippie Types," The Wall Street Journal, 7 October 1969, p. 1.

30 "Haverford's Net Coach Latest Victim of Hippies," New York Times, 5 June 1968, sec. 3, p. 54.

31 “Hair," New York Times, 11 November 1968, sec. 3, p. 65.
} 
students at NYU picketed outside of the employment office because the school would not hire a student mail carrier because he had long hair. ${ }^{32}$

Colleges and neigborhoods in large cities were not the only place that issues over hair occurred. Smaller towns (whether it be in the south, plains, or out west) had similar problems to deal with. Morgantown, West Virginia, and West Virginia University was no different. WVU experienced the new long hair craze with some resistance, but not to the extremes as the above examples. An early fall of 1966 issue of the school newspaper, the Daily Athenaeum, printed an article out of Dallas, TX about three teen-agers in Dallas who were refused admittance to R. W. Samuell High School by their principal because their hair was too long. The three students were in a rock band with two college students and stated that the reason they did not cut their hair was because they were under a recording contract which prohibited them from cutting their hair short. The boys tried to go to seven other schools and were rejected by all. The reason given by school officials for not letting them in school was that their hair would cause other students to be distracted..$^{33}$

A few weeks later, an editorial by a WVU student writer was published in the school newspaper. The overall message from the editorial was that long-haired students should be left alone:

"It is wrong, even, to refer to them ['long hairs'] as 'they' or 'them,' connotating some kind of group. They are not. Their interests and ideas very widly. One of the few things these men with long hair...have in common is their hair. It is true that a couple of 'long hairs' might have what we term 'radical ideas,' but let them have their ideas. Isn't this the country that was founded on free thought? We may not

\footnotetext{
32 “Long Haired Student Wins Support from the Pickets,” New York Times, 23 March 1967, sec. 1, p. 25.

33 “Singers Out of School; Hairy Problem," Daily Athenaeum, 14 September 1966, p. 2.
} 
agree with some of the radical ideas, but just becaue we disagree with them, should we condemn them?"34

The editorial touched off a debate over the issue of long hair. One anti-long hair reader referred to those with long hair as "fanatics" because they signed peace petitions and classified them as "trash." He then stated that many of the shorter-haired students thought "long hair plus expressions of individualism equals homosexuality and fanaticism.."35 In response one student said, "I advocate long hair when it is feminine and peace when it is feasible. Those who spare the scissors and shun the war may do so if they please, but I ask permission to attack their views, their values and their virtues, for they surely will attack mine. ${ }^{36}$ Another letter in the same issue stated: "As one of the shorter-haired students on this campus, I would like to refute a point...True individualism will be recognized without dramatic aids of long hair and unusual dress. If growing long hair by itself is a creative expression of individuality...then animals do as much unwittingly. ${ }^{37}$ The debate continued with one reader calling for the acceptance of long hair, “The length of one's hair certainly cannot be a judge of one's character, ideals, personality or politics. Society should not attempt to dictate. The decision lies with the individual. ${ }^{38}$

Certain stereotypes of those with long hair, such as drug use, seemed to be supported by some of the articles that ran in the Daily Athenaeum. The October 25, 1967 edition of the newspaper ran a cartoon of an anti-war protestor with long hair and a beard, wearing military fatigues with a patch that says "Ravi" (in reference to the Indian sitarist

\footnotetext{
34“"Long Locks: Leave 'em Alone,” Daily Athenaeum, 25 October 1966, p. 2.

35 "Long Hair Defended," Daily Athenaeum, 18 October 1966, p. 2.

36 "Long Hair Okay," Daily Athenaeum, 25 October 1966, p. 2.

37 "Animals Hairy, Too," Daily Athenaeum, 25 October 1966, p. 2.

38 "Long Hair Accepted," Daily Athenaeum, 1 November 1966, p. 2.
} 
Ravi Shankar, who was very popular amongst the counterculture) on it, and holding a sign that reads "NEVER!"39 Articles reinforcing these stereotypes were also run. One article out of Utica, New York stated: “Two long-haired, bearded New York State policemen disclosed Monday the story of their nine-month stay among hippies that led to one of the largest drug raids in the state's history. 'It's rotten. You have to live with them and eat with them,' said Investigator Gerald P. Thomas, 39, as he prepared to head home to his family in Syracuse for a shave and a haircut. ${ }^{, 40}$ Another article suggested that this sort of expression always ended in traumatically, "The confused, graying mother was left with only a basketful of shattered hopes the day her son left home to become one of the young, shaggy drug users she had always despised. Joining a discussion group of other parents with hippie sons and daughters didn’t bring her son back." ${ }^{, 41}$

If long hair stirred debate at WVU, there is little evidence that long hair created much conflict on campus. There were no coaches fired, nor were there any protests being led. The Daily Athenaeum reported one instance of discrimination against a long-haired student. In 1968, a student claimed that he was fired from his waiter job at the Twin Towers for not shaving his mustache. He soon found another job, however, at the Engineering Library. He commented that he thought, "The people in charge of the housing office should take a lesson from those fine, upstanding, liberal-minded employers at the library." The man in charge of the Housing office said that the rule could be changed if they felt they were doing an injustice to the waiters, but this was the first time it was contested. ${ }^{42}$

\footnotetext{
${ }^{39}$ Daily Athenaeum, 25 October 1967.

40 “"Hippie' Police Crack Large N.Y. Dope Ring,” Daily Athenaeum, 22 January 1969, p. 7.

41 “"Parents Lose Sons to Hippie Generation," Daily Athenaeum, 29 January 1969, p. 7.

42 “Mustache Owner Gets Employment," Daily Athenaeum, 22 March 1968, p. 2.
} 
High schools were different from colleges. The main difference was that high school children were (and for the most part still are today) not as "free." They were made to live under the rules established by their parents, their teachers, and their principals. Largely as a result of the discrimination they experienced for having long hair, students began to fight for their individual rights as high school students. Eventually, many high school student councils adopted what became known as the High School Bill of Rights. The Bill of Rights stated that high school students had the same rights that were enumerated under the United States Constitution. Among other things students had the right to form political and social organizations in the school, they could plan and carry out forums, they could strike and control student publications, and they had the right to dress and look in a way which expressed their beliefs. This included long hair. ${ }^{43}$

But how did students get to the point of needing and establishing a Bill of Rights? A look at the hair controversy is a perfect case study. From 1966 until the early seventies, students were suspended, expelled, and persecuted in high schools for the length of their hair. At Oyster Bay, Long Island, five high boys were barred from their regular classes because of their hair length. They were placed on the previously unoccupied fourth floor and were kept out of sight and communication from the rest of the twelve hundred students. Originally twelve boys were sent there, but seven cut their hair and were allowed to rejoin their classmates. The others said they were willing to stick it out "to defend the principle that we are individuals and entitled to our rights." Principal Richard Nodell responded, "It's a little educational matter. We don't forbid long hair unless it is excessive and poor in appearance." Once again we see the blurry definition of long hair. "They are in violation of a student code, majority rule, that deals

43 “Dress Code Fought," Fifth Estate, 29 September 1971, p. 10. 
with appearance. These kids aren't rebels. They have minds of their own. But they can't be different to the point where they disrupt the education of other children in the school." Letters sent home to the students' parents described three reasons why they were being punished: their long hair was upsetting the morale of the other students, it was distracting other students, and teachers felt that their teaching was being adversely affected by the "apparitions." ${ }^{44}$ As odd as these allegations may seem today, this was the argument used by practically every high school in the United States which took disciplinary action against boys with long hair.

In Forest Hills, New York, two senior honors students were barred from receiving instruction and forced to sit in the dean's office all day until they got "suitable" haircuts. The main problem here is that they could not participate in gym class and would therefore not receive the right amount of credits needed to graduate. The New York Civil Liberties Union filed a petition with the State Education Commissioner Dr. James Allen on behalf of the two boys. "The boys were excluded from class because their grooming was disruptive of the learning system," the principal claimed. ${ }^{45}$ The High School Principals Association supported the Forest Hills principal and asked Superintendent Donovan to uphold his ruling. The President of the Association said that making a civil rights case out of it is "both absurd and disruptive." 46 The superintendent ordered that the boys be returned to their classes. The principal responded by telling the superintendent that he was encouraging "anarchy." The parents also backed Principal Balsar. In a letter to the superintendent, the school's parents association supported the principal and his

\footnotetext{
44 “5 Oyster Bay Boys Pledge to Stick It Out All Term,” New York Times, 10 September 1966, sec. 1, p. 31.

45 "Long Hair Benches Two Honor Students," New York Times, 12 October 1966, sec. 6, p. 1.

46 "Principal Backed in Long Hair Case," New York Times, 13 October 1966, sec. 5, p. 48.
} 
staff "in their attempt to establish reasonable standards of personal appearance and demeanor. ${ }^{, 47}$

The position taken by administration and faculty at high schools on the hair issue was pretty standard and consistent. Most remained against "excessively" long hair and considered it to be a distraction to learning. But the question on where parents stood varied. In a 1969 Good Housekeeping Poll, seventy-six percent of the polled adults sided with the high schools and believed that they had the right to regulate student hair length. Only twenty-one percent sided with the penalized students who had long hair. If parents did not enforce an adherence to neatness, shortness, cleanliness, and conservative hair styles, then they saw no reason why the school should not take over. Going even further, a large number saw grooming as an aspect of discipline that belonged in the province of the school. Eighty percent of the respondents said that the appearance of high school boys in their town bothered them. Only sixteen percent said it did not. Of the different groups identified as being a proponent of school involvement in grooming, the most conservative were parents concerned with law, order, discipline and control, and who were worried by the falling off of standards in all areas of life. ${ }^{48}$ Some insisted that the style is "improper," while some said that they opposed it simply "on principle," since it was clearly "not right.",49 Just as long hair was a symbol of individualism and expression for students, the conservative group of parents saw it as a symbol of disrespect for wellordered life. The majority stood behind the New York mother who said, "I feel that a lot

\footnotetext{
47 "Principals Score Long Hair Ruling," New York Times, 15 October 1966, sec. 8, p. 31.

48 "Good Housekeeping Poll: Have Schools the Right to Enforce Haircuts?," Good Housekeeping, September 1968, p. 12.

${ }_{49}$ "The Long Hair Controversy," America, 12 November 1966, p. 578.
} 
of today's troubles are due to a lack of respect for authority. Somehow, it has become the thing to do to put down school officials, the police, parents, and even the President!" 50

There were many other parents, however, who were similarly concerned with the amount of overt control tactics that were taking place in public schools. One Missouri mother said, "I believe that children should not conform to old ideas and theories. The world progresses and improves through change. Although I may not approve of the way some of these youngsters look, I feel they should be allowed to experiment and learn what constitutes a good life." Others were worried in a way that was reminiscent of George Orwell's 1984, that if the school could dictate how a student looked and dressed then it would not be long before the school would be telling the student what to think. Still, others felt that the issue was simply being blown out of proportion. "What has the length of anyone's hair to do with the sort of person he is? Demand and enforce courtesy, morality and honesty_yes. Dictate trivia—no." Most argued that the students who disrupted class would have still done it regardless if their hair were short. The minority seemed to agree with what one mother from Minnesota said. "There is too much intervention today in the individual's private life by all kinds of authority. If one can't even wear one's own hair the way he wants, what is there left of this free country we live in?" But most of the parents in the country gave the impression that the hair question would someday pass as most things did. They fell in line with the Tennessee mother who said, "Hair-schmair, what's the difference? In twenty years they'll all be bald!"51

\footnotetext{
50 "Good Housekeeping Poll," p. 12.

${ }^{51}$ Ibid.
} 
Even most of the parents who felt that long hair was a passing fad, disliked their sons' long locks. Why? One answer is the fear of homosexuality. One thing that happened during the sixties was the blurring of gender lines. Boys were wearing their hair long and girls were wearing their hair short. A common misconception among parents was that if their boy had long hair, then he was a homosexual. One woman said that she would never allow her son to walk around looking like "a leftover from Greenwich Village." To her long hair, meant that a male was not a male. Long hair also became a symbol of "the emasculation of the American college man." In 1966 nine college students at Wayne State University met at a barber shop to protest "the greatest social issue of our time." They shaved their heads because they felt "men are losing their identity." 52 Psychiatrist Judd Marmor of Los Angeles, an authority on homosexuality, began to challenge publicly his colleagues and APA leaders who maintained that homosexuality was an illness rather than a normal variant of sexual behavior, and said that male deviants range from extreme femininity of physique and manner to extreme masculinity. ${ }^{53}$

Some parents were simply afraid. They were afraid that their sons and daughters would become another statistic, another product of the frightful side of society. One mother and teacher in a letter to the father of one of her students expressed this fear felt by many parents:

"Frankly, we're afraid. And in a way we've got good reason to be. Almost every day our newspapers bring us word of problem drinking, drug addiction, out-of-wedlock

\footnotetext{
52 "Youths Lose Hair for Ideal,” New York Times, 4 May 1966, sec. 2, p. 45.

${ }^{53}$ Mary Groves, "An Open Letter to the Father of A Boy Who Won't Get His Hair Cut," Good Housekeeping, November 1967, p. 62. Also see, Ken Hausman, "Pioneering Psychiatrist, Psychoanalyst Judd Marmor Dies at Age 93," Psychiatric News, 6 February 2004, p. 2.
} 
pregnancy. No wonder we're determined to be on guard and not to take the easy way out of doing nothing. 'If we're strict and vigilant,' we say to ourselves, 'these horrible things won't happen to our children. Consciously or subconsciously, we brace ourselves to battle evil influences. More and more, the social scientists tell us what our own hearts confirm: We have to blow the whistle on our children until they're old enough to blow the whistle on themselves." 54

Different methods other than removing students from classes were used to get boys to cut their hair. In Concord, New Hampshire, school administrator Norman Limoges took eighteen students from their classrooms, put them on a bus, sent them to a barber shop, and had their hair sheared. ${ }^{55}$ Similarly, one student in San Diego, California, sued his teacher for assault and battery for cutting his hair in class. The teacher claimed that he had permission from the school's administration to do it, but ended up settling out of court. ${ }^{56}$ A student in High Bridge, New Jersey, did not fare as well. After being clipped by his teacher, the student's parents also filed for assault and battery charges. Although the teacher was reprimanded by the superintendent, municipal court Judge Wilson Anderson dismissed the case saying that it fell under the corporal punishment provisions of school law. ${ }^{57}$

Some schools began implementing policies before major controversy occurred. The school boards in Roselle, New Jersey, and Pompton Lakes, New Jersey, decided that boys' hair was getting too long. The Roselle board approved new comprehensive dress code rules, but in Pompton Lakes, hair was specifically addressed. The code prohibited “excessively long hair on boys." The school's principal felt the new codes were needed

\footnotetext{
${ }^{54}$ Ibid.

${ }^{55}$ Joan Cook, "In the 60's, Hair Was a Fighting Word," New York Times, 31 December 1969, sec. 1, p. 29.

56 "Suit Over Haircut Settled," New York Times, 31 May 1967, sec. 5, p. 14.

57 "School Reprimands Teacher Who Cut Student's Hair," New York Times, 19 November 1967, sec. 4, p.
} 43. 
because "A few boys have felt it was up to them to decide if their hair was too long. The school is a place of business. Dress must be appropriate." He also pointed out that a majority of the school's students had voted for it. One of the problems that once again arose was the question of what was a suitable length for boy's hair. Opinions differed, but it was eventually decided that "ears are usually considered to mark the borderline of propriety. ${ }^{.58}$

Some students even offered their own compromises. At Fordson High School Assistant Principal Ray Martin told students that their hair was not to go past their collar or earlobes. Some students said that they were willing to get wigs and wear them to school, but Martin still threatened suspension to all long-haired students regardless of whether they were wearing a wig or not (he later clarified that girls were allowed hair past their earlobes). It seemed that Martin did back down, because he did not take any action against students who wore wigs. This seemed like a reasonable solution, but the problem was that many students could not afford wigs which cost as much as thirty dollars. Martin pointed out, "They care more about how you look than about your education. ${ }^{, 59}$

By 1967 students were beginning to fight for their legal right to wear long hair. Initially, the judicial system shied away from the issue, leaving final arbitration of local school disputes in the hands of states boards of education. Just as in the ruling of Judge Wilson Anderson, many judges were uneasy about taking such cases because they did not feel it was within their authority to handle those situations which often fell under the rule of the education system. It is also possible that many judges feared that the students

\footnotetext{
58 “2 Jersey Boards Frown on Miniskirts,” New York Times, 13 April 1967, sec. 2, p. 45.

59 "Dress Code Fought."
} 
would win the cases. In Trenton, New Jersey, a fifteen year old ninth-grader Francis Pelletreau was expelled from school for his "Beatle-length" haircut. The acting State Commissioner of Education John Clayton originally upheld the ruling: "It is inconceivable that a pupil must be allowed to dress or appear in some such bizarre, grotesque or outlandish fashion." The New Jersey chapter of the American Civil Liberties Union called his decision a "monument to conformity." They asserted that it violated a 1925 Supreme Court ruling that forbade the use of state power to "standardize its children. ${ }^{, 60}$ Six months after the ruling was upheld, the State Board of Education ruled unanimously that the boy should return to school: "A school regulation forbidding long hair, in effect, regulates outside of school conduct. It is not possible to have short hair in school and revert to longer hair at home."

The New York State Education Department commented on the incident, saying that long hair on boys was permissible in the state's schools "as long as it doesn't interfere with his health or safety. That's his privilege. That's the official position of the department." ${ }^{\prime 61}$ Not only did they comment, but they acted upon it as well. Acting Commissioner Ewald Nyquist heard three separate dress code cases and decided that schools could not prevent boys from wearing their hair long. "The standards of taste of a previous generation are an insufficient basis for the imposition of restrictions upon students of today." He held that because dress codes were concerned with matters of taste then they were not enforceable by disciplinary action against any student who failed to abide by them. The only dress codes that could be enforced were ones that were

\footnotetext{
60 “A School That Cut Long-Haired Youth From Roll Upheld,” New York Times, 10 March 1967, sec. 7, p. 41.

61 “Jersey Upsets a School Ruling Barring Long-Haired Students,” New York Times, 7 September 1967, sec. 8 , pg. 7 .
} 
related to health, safety, or were linked to specific educational activities. According to the New York Civil Liberties Union it was a landmark decision. The outcome "once and for all makes it clear that public school principals and superintendents have no power to suspend or otherwise discipline students for what the school considers improper dress.

Although some students were having trouble getting their cases heard in courts, some sympathy was rising. In October 1968, the United States Supreme Court refused to hear the case of three Dallas boys who were kicked out of school for having long hair. Justice William O. Douglas filed a sharp disagreement by saying he had supposed a nation founded on the Declaration of Independence would permit "idiosyncrasies to flourish, especially when they concern the image of one's personality and his philosophy toward Government and his fellow men." It was his opinion that the Court should have heard the case. ${ }^{63}$

By 1969 across the country, federal courts began to engage the issue. Federal Judge James Doyle declared a high school ban against long hair to be unconstitutional and that Williams Bay High School in Wisconsin should reinstate a previously expelled student. ${ }^{64}$ Judge Charles E. Wyzansky of Boston also reaffirmed a previous ruling that school officials may not suspend students because of their hair. ${ }^{65}$

How far would these court cases go? Would they make it to the level of the United States Supreme Court? If the cases did make it to that level then, what would the ruling be? Savannah, Georgia, Federal Court Judge Alexander Lawrence upheld a school board rule against long hair for students but urged them to take the case to the United

\footnotetext{
62 "State School Chief Throws Out Dress Codes Based on Custom," New York Times, 29 July 1969, sec. 3, p. 25.

63 "Long-Hair Youths Find A Champion in Douglas,” New York Times, 15 October 1968, sec. 1, p. 30.

64 "Hairy Victory," Time, 15 June 1970, p. 61.

65 “Boston Upholds Long Hair," New York Times, 26 October 1969, sec. 1, p. 46.
} 
States Supreme Court of Appeals. ${ }^{66}$ In another case the U.S. Court of Appeals ruled in favor of high school student James Stull of Beaver High School in Pennsylvania who was suspended for three dress code violations. It ruled that a male school pupil had a constitutional right to wear his hair long. ${ }^{67}$ Some state Senates even got into the act. The New York State Senate approved a bill which limited local boards of education to regulating the dress and appearance of students only insofar as their health, safety, and full participation in school activities were affected. The supporters of the bill agreed that it would prevent boards from "whims" in regulating long hair. ${ }^{68}$

But the Supreme Court was not as quick to give its support. In February 1971 a balding Justice Hugo L. Black of the U.S. Supreme Court ruled that the Constitution did not give high school boys the right to wear their hair long. Going even further, he concluded that lawyers should not be pressing the Supreme Court with "emergency motions," implying that the nation will be in crisis unless long hair is allowed. The ruling came as result of an El Paso boy who wanted the Justice to suspend the school's rule against long hair while a suit against the rule moved through the courts. ${ }^{69}$ Nevertheless, some the Supreme Court Justices were more open to discussion. In discussing the hair style cases, Justice William Douglas identified eight appeals courts in various circuits where the hair issue was in question. Four of them upheld the school's rulings, while four struck them down. It was definitely not an open and shut case for the legal system. Justice Douglas commented, "I can conceive of no more compelling reason to exercise

\footnotetext{
66 "Hair Rule Is Upheld,” New York Times, 13 September 1970, sec. 3, p. 79.

67 "Courts Back Long Hair," New York Times, 15 April 1972, sec. 2, p. 63.

68 "Assembly Backs Aides To Doctors," New York Times, 4 June 1971, sec. 3, p. 15.

69 "Right To Long Hair Is Denied By Justice,” New York Times, 14 February 1971, sec. 3, p. 111.
} 
our discretionary jurisdiction than a conflict of such magnitude, on an issue of importance bearing on First Amendment and Ninth Amendment rights. ${ }^{, 70}$

Throughout the 1960s and into the 1970s over one hundred hair cases were appealed to the United States Circuit Courts of Appeals and nine were appealed all the way to the United States Supreme Court. In a landmark 1969 case, Tinker v. Des Moines Independent Community School District, the U.S. Supreme Court vaguely confirmed the status of high school students as citizens. "The case became the touchstone for federal and appellate court judges who heard haircut cases in the late 1960s and early 1970s. Since the ambiguity of the Courts ruling allowed lower court judges to rule either for or against regulating long hair on high school boys and justified limited citizenship for minors...." Justice Abe Fortas, who penned the majority opinion, wrote: "First Amendment rights, applied in light of the special characteristics of the school environment, are available to teachers and students. It can hardly be argued that either students or teachers shed their constitutional rights at the schoolhouse gate. This has been the unmistakable holding of this Court for almost fifty years." Fortas added: "In our system, state-operated schools may not be enclaves of totalitarianism." ${ }^{71}$

One incident that made its way through the courts involved Casey Karr of El Paso, Texas. Karr came to Coronado High School after one summer with long hair. $\mathrm{He}$ was told to not come back until he cut his hair. What did Karr do? He decided to sue the school. Twenty-one other boys decided to keep their long hair and not abide by the hair regulations, but backed down when the school threatened them with expulsion. Karr's

\footnotetext{
70 “Court Declines to Review Prohibition On Cigarette Ads Over Radio and TV,” New York Times, 28 March 1972, sec. 1, p. 31.

${ }^{71}$ Gael Graham, "Flaunting the Freak Flag: Karr v. Schmidt and the Great Hair Debate in American High Schools, 1965-1975," Journal of American History 91 (September 2004): 523, 528.
} 
father was quoted as saying, "Nobody told me how to cut my hair when I was in school." He testified at his son's trial and stated that he did not want his son to break the rules simply for something to do, but because he stood for something that he believed. The first case went to the school board where the hair ruling was upheld. Karr admitted in a recent interview that he felt the board "didn't like young high school kids trying to buck the system. They saw [opposition to the rules] as part of the protest era of the late 1960s. . .. It threatened their authority. They didn't want some punk telling them how to run their operation."

After the board's ruling, Kerr, his parents, and the ACLU sued in federal court, citing that the school had violated his First, Ninth, and Fourteenth Amendment rights. "In their testimony, Karr and his witnesses emphasized students' individual rights, although they simultaneously argued that the school dress code usurped the rights of parents to oversee their children's appearance. They also attempted to refute the scattershot approach of the defendants, who attacked masculine long hair from half a dozen different angles." The school used the argument that his long hair disrupted classes and students along with the hygiene and safety dangers of having long hair. ${ }^{72}$ Judge Suttle handed down his opinion: "one's choice of hair style is constitutionally protected and ... the State may invade this interest only upon a showing of compelling reason." One by one, he demolished the rationalizations for the rule offered by officials. He then cut to the heart of the matter:

"From specific discipline problems, we proceed to the general proposition advanced by virtually all of defendants' witnesses that a rule such as the one here attacked must be obeyed simply because it is there. ... Besides the fact that such an argument would justify any rule, regardless of how

\footnotetext{
${ }^{72}$ Ibid, p. 529-531.
} 
unreasonable, arbitrary, or capricious, the Court finds, from the preponderance of the evidence in the case, that, again, requiring adherence to the hair-cut rule is not reasonably related to the professed goal. Instead of teaching respect for society's laws or rules, enforcement of an unreasonable rule undermines respect for other rules and laws which are reasonable and deserve adherence. At best, the rule here attacked teaches only conformity and unreasoning submission to authority; at worst, it results in disrespect for all rules and distrust of authority., ${ }^{, 73}$

In the early seventies even as hair length was being fought at the federal level, some local communities continued to struggle with the issue. In Marietta, Georgia, the school board adopted a new dress code which resulted in forty-three students being sent home. The new code stated that boys were to tuck their shirts in and that "hair length will not be permitted to go beyond the top of collar nor below the earlobe." Students did not feel the board would go through with the suspensions even though three years before a boy was arrested for refusing to cut his hair. One student made the comment to Principal Wolfe, "If you go through with this you're going to have to kick everybody out." To which the principal replied, "That's exactly what I want to do." Although the students were surprised by the actions, they felt they knew what the motivation behind the board's action was: "Last year we had a lot of stuff about drugs so they think if they get rid of the hair they can get rid of the drugs." As a result of the suspensions, eight of the punished boys put together a town meeting at a local church. In addition to the students at the meeting, seventy adults showed up. The parents were divided between ones who disagreed with the school board and those who simply wanted an explanation. Although no faculty or board members showed up to the meeting, the mayor attended. After one parent suggested a two week suspension of the rules until the school board

${ }^{73}$ Ibid, p. 534. 
could meet, the mayor tried to contact the board members to get an emergency meeting called. After this was unsuccessful, the mayor brought it to the attention of those in attendance that the board had a regular meeting scheduled in ten days. ${ }^{74}$

Three hundred students, supporters, and parents attended the school board meeting. The meeting began with a representative from the ACLU explaining that they had gone to U.S. District Court Judge O'Kelly asking him to declare the dress code unconstitutional and that the judge issue a restraining order to force the school board to readmit the students while the legal case was being decided. One of the problems addressed by the students was that punishments were handed out arbitrarily and that exceptions were made for the more outstanding students. Parent Carolyn Brady addressed this issue and called it "blatant discrimination in enforcement." She claimed that a number of students were allowed to remain in school even though they violated the code. When asked for specific names, she did not supply them, but four long-haired boys in attendance stood up and said that they were still in school. It was the school board's defense that hair length and dress were a symbol that the students elected to withdraw themselves from the main flow of the student body.

The board's eventual ruling was that the suspended students had been violating the code and that the code should remain unchanged. They also found that "the code has been enforced without partiality and directs its continued enforcement without partiality." While parents and students alike began to call for a walk-out, the attorney for the ACLU announced that the judge had signed the temporary restraining order, so the students were allowed back in school. The chairman closed the meeting with, "I think the situation will

\footnotetext{
74 “Longhairs Fight Back,” Great Speckled Bird, 6 September 1971, pp. 6-7.
} 
resolve itself." ${ }^{, 75}$ Students were beginning to initiate the fight for their rights on their own. Even though the decision did not initially fall in their favor, they represented a certain spirit of the 1960s that was evident throughout all of society. It was an attitude of rebellion and a willingness to fight to the end for something about which a strong belief was held.

There were cases, however, where the long hair issue was taken too far and handled poorly; cases where the individuality and the symbolic purpose of long hair was not the issue. This was occurring as late as 1974. Billy Epperson was born with a deformed head. Because of this his parents elected to grow their son's hair long to help alleviate some embarrassment. As a kindergarten student, Billy's hair attracted the attention of school authorities at Golden Acres School in Pasadena, Texas. The Pasadena Independent School District's grooming code stated that hair should be worn above the collar and ears and out of the eyes. The school's principal advised Billy's parents to get him a haircut or he would be removed from school. Mr. and Mrs. Epperson apparently tried to contact the school and the superintendent but could not get an appointment with them. As a result the mother contacted a local reporter. Before long, the case was in the public's eye. The school may have been willing to make an exception, but because the public was now aware, the school officials, "who feared a widely publicized exception would become a precedent for violations of the dress and grooming code," felt the case demanded a rigid and inflexible position. As the situation drew national attention, both sides offered up compromises. The school negotiated with a required trim of one-half

\footnotetext{
75 “Marietta Long Hairs,” Great Speckled Bird, 20 September 1971, pp. 4-5.
} 
inch. But were "flatly turned down." The parents on the other hand offered to take their son to a stylist and have it styled, but the school would not comply. ${ }^{76}$

As in most cases, the Eppersons tried to get a court to order Billy back to school until the issue was solved, but the judge denied jurisdiction. The family was set to meet with the superintendent but was turned away and ordered to meet in front of the board. Just how out of hand had the matter gotten? Billy's lawyer received a telephone threat that Billy would be killed if he went to the hearing. But Billy did go to the hearing, and, as expected, the board unanimously rejected the plea. Billy stayed out of school while the parents waited for a court hearing, but Mrs. Epperson did not feel anger until one afternoon. She was standing in her front yard with Billy when some middle school students got off the PISD bus and three of the boys had longer hair than Billy. ${ }^{77}$

Although arguments for or against dress codes do not necessarily apply in this case, it is an extreme example of how contentious of an issue long hair had become and how fearful schools were about granting exceptions. Had the district truly lived under an all-encompassing rule Mrs. Epperson would have been spared the anger she felt, and Billy might not have even been sent home in the first place. It is also important to note that had the Eppersons been able to get in touch with the school initially, the entire incident could have been avoided. ${ }^{78}$

It seems as though most cases against long-haired boys were often overblown and taken to the extreme in order to establish certain codes and regulations. But there were instances where regulation was needed. In Sacramento, California, a man was suspended from his job for thirty days because of his long hair. The problem? He was a firefighter

\footnotetext{
${ }^{76}$ Charles Stough, "Long Hair and Short Tempers: A Case History,” School Management, 1974, pp. 20-34.

${ }^{77}$ Ibid.

${ }^{78}$ Ibid.
} 
and his long hair did indeed pose a fire hazard. The Fire Chief commented by calling his long hair "an unsafe condition which could be injurious to you and to others around you during fire fighting operations.. ${ }^{, 79}$ Cases like these where personal injury may be involved made sense when enforcing hair length regulations. A mechanic with long hair which could easily get caught in moving parts should be required to have his hair cut a certain length. Or, a food handler who has the potential to get hair into food and violate health regulations should also be required to have their hair a certain length or simply wear a hair net. But how many of the young boys in high school who had long hair caused serious risk to themselves or others around them? The answer is not many if any at all. Rulings made against these individuals were made as a statement of authority and rule. Whether regulations were appropriate or not did not matter. They were approved codes and they were going to be enforced to the maximum at all times.

While long hair controversies may have been present in towns all across America regardless of size, it was not necessarily the same for small town high schools. The long hair issue at the high school level in Morgantown, West Virginia, for example, did not seem to exist like it did in most other places across the country. There were no mentions of suspensions, expulsions, or even disciplinary problems stemming from longer hair in the Daily Athenaeum. Could this just be because the paper did not feel the need to mention such local topics? Well, it was shown that the issue of long hair in high schools was a topic that writers were not afraid to cover, which is proven by the article published about the three students in Texas. Also, there was a local section in practically every paper published during the period. So, it would seem that Morgantown did not really have to face these concerns. After examining various high school yearbooks from the

\footnotetext{
79 “Fireman a Fire Hazard," New York Times, 21 June 1970, sec. 1, p. 55.
} 
Morgantown area, one can clearly tell why long hair was not an issue. Few Morgantown youth wore long hair prior to the period when it became socially acceptable and stylish.

It is important to note, that when examining the yearbooks, mainly seniors were examined because they are the ones who seem to set the trends that underclassmen will follow. At Morgantown High School in 1966, 1 senior of the 219 boys pictured had shaggy hair. ${ }^{80}$ It was not necessarily trimmed and neat around the edges. In 1967 there were 4 students of the 194 boys pictured who had long hair. ${ }^{81}$ The number had risen in 1970 to 10 out of 229 pictured $^{82}$ and there were 18 boys with long hair pictured in $1971 .^{83}$ By 1970 one could tell that the hair was getting slightly longer on top as the years progressed, but it was still not the length of what was considered popular and in style nationally. Long sideburns, however, did seem to infiltrate the area faster and be much more prevalent than long hair. Unfortunately, no yearbooks were available from 19681969, but the trend can be seen. Although the numbers rose, by 1971 there were still fewer than ten percent of high school seniors with long hair at Morgantown High School. The same can be seen at University High School. The only two yearbooks available for the time period were from 1967 and 1973, but a similar pattern can still be seen. In 1967 only 1 of the 87 pictured seniors had long hair, ${ }^{84}$ and by stark contrast there were 37 of 68 seniors pictured with long hair in 1973; making fifty-four percent of the male students as having long hair. ${ }^{85}$ Since there were no yearbooks available for Morgantown High School from 1971 to 1981, a similar pattern can be assumed. The reason, as we can see,

\footnotetext{
${ }^{80}$ The Mohigan, Morgantown High School, 1966.

${ }^{81}$ The Mohigan, Morgantown High School, 1967.

82 The Mohigan, Morgantown High School, 1970.

83 The Mohigan, Morgantown High School, 1971.

84 The Little Monticola, University High School 1967.

85 The Little Monticola, University High School 1973.
} 
that there were no disruptions due to long hair in high schools in Morgantown is because young men were not growing their hair long until 1972-1973 when long hair had become socially acceptable. The trend of long hair in Morgantown did not hit the teen-age level until 1973, which is about five years longer than it took a good majority of the country to develop this trend.

During the late sixties and early seventies, educators fought to control the length of their male students' locks. As historian Gael Graham observed, "To school officials, long hair on high school boys posed both a real and a symbolic threat." School administrators "sought to maintain their authority over students at a time when all authority seemed subject to interrogation, ridicule, and even dismissal. Thus by growing long hair in defiance of school rules, high school boys challenged the authority of the rule makers. But the symbolism of the threat mattered as much as the sheer flouting of authority." 86 What started out as specific young people growing their hair long to showcase their personality, became an overarching statement for rebellious youth in a mutinous society. Hair was no longer the issue and it told little about the attitudes and ideals of the person underneath. The issue became authority, individual rights, and the right to challenge that authority. One writer commented, "They [persons in authority] will fight to try to keep control., ${ }^{, 87}$ And they did fight. They fought to keep control, and the youth of America fought to usurp that control.

\footnotetext{
${ }^{86}$ Op. cit., Graham, "Freak Flag,” p. 542-543.

${ }^{87}$ Ibid.
} 


\section{Working Class Hero: The Workplace and Problems with Hair Length}

Struggles over long hair also occurred in other realms where its opponents had institutional power. This chapter explores the contest over hair length in places of employment, broadly defined to include the military and the traditional work place. Dissension within the military increased dramatically during the Vietnam War era. Long hair represented a visible challenge to military discipline. Relations were equally contentious in many workplaces. Many young workers, including numerous Vietnam veterans, revolted against the monotony of highly fragmented jobs and shop discipline. This youthful workforce seemed to be rejecting their parents' acquisitive values. Sporting long hair, their discontent was often expressed through higher levels of absenteeism, refusal to work overtime, grievances, wildcat strikes, and contract rejections. Conflict over hair was a visible manifestation of managerial efforts to control young workers.

The war in Vietnam was not only unpopular amongst many American youths living and working in the United States, but also with many of the soldiers serving both abroad and at home. All across America, men and women were fighting against the war and those who supported it. America's youth in the anti-war movement were led by student groups. Students in the antiwar movement articulated the complaints of the young against the old. They were the first to challenge the white, old, rich men in charge of foreign policy. This theory as to why the youth revolted is called the generations theory, which calls it a generational revolt over clashing world views. ${ }^{1}$ The movement

\footnotetext{
${ }^{1}$ Rhodri Jeffreys-Jones, Peace Now! American Society and the Ending of the Vietnam War, (Yale University Press, 1999), p. 43-44 and 46-48.
} 
also included Vietnam veterans. From the movement's inception, veterans of previous foreign wars were an integral part of the anti-Vietnam War movement. One of the first large demonstrations against the war in Vietnam occurred on October 15, 1965 in New York City. The march and rally were organized by the Fifth Avenue Peace Parade Committee and supported by many pacifist and anti-war organizations. The event drew almost 25,000 people including many World War II veterans. Many of those in attendance were greeted with the words "coward" and "traitor" by war supporters. These former soldiers would form the Ad Hoc Committee of Veterans for Peace in Vietnam and would later galvanize into the Veterans for Peace. The Veterans for Peace also played a large role in getting Vietnam veteran membership in the antiwar movement. Veteran for Peace delegate Maury Colow said, "We must do all in our power to get them on the side of peace. ${ }^{2}$ Author Jerry Lembcke states:

"Veterans' groups led some of the earliest protest marches against the war, and tactics such as draft card burning, which became emblematic of the anti-war movement, and the turning-in of service medals as an act of protest, which became the hallmark of anti-war Vietnam veterans in the early 1970s, may have been foreshadowed by similar actions taken in the mid-1960s by veterans of previous wars." 3

According to historian Rhodri Jefferies-Jones, "The war was ghastly; the belligerents on both sides committed appalling crimes; thousands of young Americans returned home in an unhinged and brutalized state of mind." veterans' participation in the anti-war effort.

\footnotetext{
${ }^{2}$ Jerry Lembcke, The Spitting Image: Myth, Memory, and the Legacy of Vietnam. (New York University Press, 1998), p. 33.

${ }^{3}$ Ibid, p. 29.

${ }^{4}$ Ibid, p. 46-48.
} 
The war itself was not the only thing that men and women across the country were upset about. The draft was also a major point of contention. One of the most widely understood actions of some antiwar supporters was the act of draft resistance. One point of view held by some people today considers draft resistors to merely be draft “dodgers." Michael S. Foley argues that draft resistors were the antiwar movement's equivalent to the civil rights movement's Freedom Riders and lunch-counter sit-in participants. Whether it was through draft card burnings or draft card turn-ins, draft resistors had a clear interpretation of the problem which was fueled by an intense urgency to act. "Draft resisters and their allies, like the abolitionists and the young civil rights activists, pushed their movement toward confronting their own government and demanding an end to the violence of war.",

Soldiers, themselves, also experienced the breakdown of discipline and began challenging the traditional values of the military. If young people at home were challenging the traditions and structures of their parents and bosses, then soldiers had more than enough ammunition in their arsenal as the U.S. military was one of the most structured and tradition-rich institutions in America. Military traditions and attitudes of soldiers broke down in the midst of the terrifying experience. Whatever optimism and hope that many young men previously took into the service, their experience in Vietnam made their eventual bitterness towards the horrors of war even more demoralizing. Many soldiers felt victimized and used for others' gain. Author Landon Jones notes, "The war, coming at a time of youthful transition for the first half of the baby-boom generation, also brought with it another disturbing indication that their great expectations might not be

\footnotetext{
${ }^{5}$ Michael S. Foley, Confronting the War Machine: Draft Resistance During the Vietnam War. (The University of North Carolina Press, 2003), p. 9, 15-16.
} 
met....They had been young and idealistic and Vietnam made them old and cynical..”6 Christian Appy notes that soldiers in Vietnam "gleaned some personal satisfaction in their noncompliance with military regulations." ${ }^{7}$

Soldiers used various methods to resist military authority. One army psychiatrist noted: "The army seems on the verge of collapse. The command structure is rapidly losing control of the troops both in minor aspects and in some very tragic large ones. The collapse is taking place in three distinct and related facets - drugs, disregard for authority, and violence." ${ }^{8}$ Drug use became rampant amongst soldiers in Vietnam. As high as thirty percent became drug users while stationed in Vietnam. Desertion rates also rose. By 1971, almost 74 out of every 1000 soldiers deserted; this was the highest desertion rate in modern American history. ${ }^{9}$ The most extreme method of challenging authority was the act of fragging. Fragging was when soldiers would assassinate an unpopular member of their own unit by dropping a fragmentation grenade in their tent at night. A hand grenade was used because it would not leave any fingerprints, and because a ballistics test could not be done. Intentional "friendly fire" was also another technique that was used. In both cases the death was blaimed on the enemy and because of the soldier's unpopularity, nobody would contradict the story. The intended victim of a fragging was sometimes given warnings, the first of which might be a grenade pin on the sheet of the victim, and later on, a tear gas grenade. The targets of fragging were mostly incompetent commanding officers or senior noncommissioned officers. During the

\footnotetext{
${ }^{6}$ Landon Jones, Great Expectations: America and the Baby Boom Generation. (Coward, McCann, and Geoghegan: New York, 1980), p. 103.

7 Christian Appy, Working-Class War: American Combat Soldiers and Vietnam. (University of North Carolina Press: Chapel Hill, N.C., 1993), p. 285.

${ }^{8}$ Philip G. Hester, Philip S. Kopala, and Philip Worchel, "Collective Protest and Legitimacy of Authority." Journal of Conflict Resolution 18, No. 1 (March 1974): p. 38.

${ }^{9}$ Edward K. Spann, Democracy's Children: The Young Rebels of the 1960 s and the Power of Ideals. (A Scholarly Resources, Inc.: Wilmington, DE, 2003), p. 121.
} 
Vietnam War, at least 600 American officers were murdered by their own troops in documented cases, and as many as 1,400 other officers' deaths could not be explained. As many as $25 \%$ of all officer casualties during the war were due to fragging. ${ }^{10}$ Total insubordination and combat refusal was one of the most common forms of resistance. One soldier was noted as saying, "We religiously avoided the bad guys. We worked hard on what we called search and avoid." Another soldier was told by his officer that he would receive an Article 15 for refusing to go into battle. The soldier responded, "I refuse the article 15, I want a court-martial."

Soldiers serving at U.S. bases also resisted authority. They published over 300 antiwar newspapers, sometimes refused to go to Vietnam, and often committed "small, daily acts of resistance." One soldier remembered, "So little by little, it might be a truck that was neglected, it might be the tip of a wing that was damaged, just anything to keep [the war effort] off-balance."12 Many G.I. antiwar organizations were also founded, including the Movement for a Democratic Military, the Concerned Officers Movement, Stop Our Ships, and GIs United Against the War in Vietnam.

Just as students and young men across the nation were growing their hair out as part of their revolt against authority, soldiers in military were doing the same. The modern military, which had always been a safe haven for neat, clean-shaven, crew cut, traditional American values, now saw many of its members fighting those traditions as they grew long hair and beards. Reactions within the military's ranks were equivalent to what was happening in the civilian world. In some situations, men with long hair, beards,

\footnotetext{
${ }^{10}$ Steve Hesske, "They Dare Not Speak Its Name," 11 October 2006, http://www.newdemocracyworld.org/War/fragging.htm.

${ }^{11}$ Richard Moser, The New Winter Soldiers: GI and Veteran Dissent During the Vietnam Era. (Rutgers University Press, 1996), p. 54 and 46.

${ }^{12}$ Op.cit. Moser, New Winter Soldiers, p. 73.
} 
or Afro haircuts were completely outlawed on military bases. At Bergstrom Air Force Base in Austin, Texas, rules to "prevent those extremes of dress and personal appearance which so far deviate from acceptable norms of our military community as to produce detrimental effects upon the morale of its military members" from entering community areas were put in place. Those community areas included the base exchange, commissary, service station, snack bars, library, theater, chapel, clubs, barbershop, bowling alley, banks, and buses. ${ }^{13}$

Soldiers faced even harsher penalties than simply being banned from certain areas. James Wallace, a Marine Corp reservist out of San Diego, was court-martialed and convicted for failing to comply with military regulations which had stated that his hair be no longer than three inches long. His sentence was 21 days confinement at hard labor, a reduction in rank to private, and the loss of one day's pay of $\$ 60$. While he was being tried, fourteen other soldiers were awaiting trial on similar issues. ${ }^{14}$ Eight others who refused to get the military style haircuts were also given similar sentences for failure to obey orders. They contended that "their military duty was only on one weekend a month and that since they were civilians the rest of the time they should be under less stringent hair regulations than full-time marines." ${ }^{\text {"15 }}$ Many bases banned "fad" haircuts and required that hair be "closely trimmed" and "evenly graduated." This was the case which Airman August Doyle faced. He was court-martialed after refusing to cut his Afro after his commanding officer told him to do so. His lawyers, Captain Robert F. Stewart, Jr. and Captain Grover G. Jackson, argued that Doyle's haircut was a symbolic act and form

\footnotetext{
13 “Air Base in Texas Outlaws “Afros, Beards and Curlers," New York Times, 5 October 1969, sec. S, p. 20.

14 “Marine Gets 21 Days for Letting Hair Grow,” New York Times, 15 June 1970, p. 42.

15 “Eight Marine Reservists Demoted Over Long Hair,” New York Times, 11 August 1970, p. 14.
} 
of expression. The commanding officer's order for him to cut his hair had infringed upon his constitutionally protected freedom of expression as an American citizen. Although Doyle was convicted, his lawyers continued to argue that the state could only infringe upon free expression when it had reasonable justification. ${ }^{16}$

While the military seemingly tried to make concessions towards the men who were rebelling against traditional military fashion, considerable regulations were still in place. For example, the Army in the summer of 1970 said that they would allow sideburns and mustaches. Sideburns, however, were to be kept neatly trimmed and with no flare at the base. They were to be even and extend no lower than the center of the ear. Mustaches were to be neatly trimmed and were not to have "a bristly or ragged appearance, extend beyond the ends of the upper lip and not cover any part of the upper lip." While the military was no longer allowed to cut a soldier's hair shorter than one inch without personal permission, hair over three inches long, goatees, and beards were still all banned. ${ }^{17}$

Traditional workplaces were also facing their own rank and file battles in the sixties as they also saw the contest over long hair take place within their walls. By the mid fifties, most unions had abandoned control issues like work speedup and safety in return for wage increases that added to purchasing power and fringe benefits that added to security. Industrial workers then used their bargaining power to buy into the new era of mass consumption and suburbanization. Committed to reducing worker militancy, union leadership also became more removed from the rank and file. The routinization of

\footnotetext{
16 “Airman Gets Jail in Trial on Afro Cut,” New York Times, 11 December 1969, p. 37.

17 “New Army Code Allows G.I.'s to Have Mustaches," New York Times, 1 June 1970, p.13.
} 
the grievance procedure and the bureaucratization of the union structure further extended the gap between elected officials and members on the shop floor. ${ }^{18}$

Young workers in the late " 60 s and early ' 70 s increasingly rebelled against arbitrary authority that characterized both union and non-union workplaces. Those rebels were often characterized as sporting long hair. Many of them were Vietnam veterans who already felt alienated from their experiences in the military. Indeed, almost eighty percent of those who served, fought, and died in Vietnam were of working-class and poor backgrounds. ${ }^{19}$ Young workers, veterans and non-veterans alike—alienated from authority figures - were more likely than older workers to resist the changes that had occurred in post-war factories. In 1972 one author observed:

Young workers are more able than most of their parents to perceive their lack of control over the work situation. The longer duration of education for the younger generation has led to a lower degree of socialization into work patterns. Socialization is a function of being able to act practically within the ongoing society, and the greater amount of the younger workers' lives not spent in working or having available the ability to work creates counter-productive behavior patterns. Their parents, who began work earlier, were conditioned more easily; furthermore, their past militancy was broken down by long struggles, defeats, elusive minor gains, and betrayals by integrated and cautious union hierarchies. ${ }^{20}$

Not only did workers feel they were unable to control their work situation, but many felt that the unions were failing to defend their rights. Unions were failing to shield their workers from rising productivity, the intensity of the pace of work speedup, the worsening conditions on the shop floor, and automation, which often caused workers to perform unsatisfying tasks.

\footnotetext{
${ }^{18}$ Green, The World of the Worker, p. 202-205.

${ }^{19}$ Op. cit, Appy, Working-Class War.

${ }^{20}$ Nadine Felton, et al, “A New Generation of Workers," Liberation 17 (August 1972): p. 38.
} 
Unlike their parents, this new generation that entered the factories in the sixties and early seventies had little fear of poverty and insecurity. James Green observes that "they were more educated and less easily intimidated by arbitrary authority" as most "young production workers shared anti-authoritarian values" of their college educated peers who were active in the student movement. The younger workers, especially blacks and women, had no tradition of loyalty to the union. The men who dominated union leadership were simply seen as a group of bureaucrats. ${ }^{21}$ One bitter tuna fish factory worker said:

"Why should you put out for them? Why should I care about a line lady who's rushing around saying she wants her fish by three-twelve? Why should you put out when you're nothing to them as soon as you stop skinning fish? You're not even as good as a machine, because they wouldn't leave a broken machine just sitting on a bench in the locker room...Every contract time we have to fight the company and the union.",22

One example that symbolized youthful workers' discontent was a strike at the new General Motors plant in Lordstown, Ohio. The strike was a reaction against automation, authoriantarianism, and the dehumanization in the division of labor, all of which were the cause for worker alienation. In 1971 the new managers attempted to increase production in order to reduce absenteeism, which was a response to alienating conditions. They blamed absenteeism for the drop in profit margins in the late sixties and, therefore, increased the speed of the assembly line from 60 to 100 cars an hour, adopted competitive overtime, laid off unproductive workers, set new production standards, and buried grievances. Lordstown had a young and "predominantly long-

\footnotetext{
${ }^{21}$ Green, The World of the Worker, p. 219.

${ }^{22}$ Barbara Garson, All the Livelong Day: The Meaning and Demeaning of Routine Work (New York: 1975) p. 39-42.
} 
haired workforce," many of whom were veterans. They "seemed to reflect the new sensiblility of the sixties." These workers were reluctant to accept the degradation and alienation to which their Depression era parents were subjected. They were now concerned with social aspects of the job. As a result, they staged a slowdown strike during which they refused to produce at the new levels. There is a parallel between such worker revolts and the revolt within the military against the war. Vietnam veterans had not abandoned their hostility towards arbitrary authority and refused to take "bullshit from them. ${ }^{23}$

In the workplace, young employees often ran into conflict due to their lengthening hair. On-the-job harassment was common. Twenty-four year old apprentice carpenter Steve Boswell said of his long hair on the job, "My first week the superintendent told me to go see my hairdresser, and nobody else spoke to me at all." Carpenter Russ Tune claimed that there is always a special kind of test put on the longhairs. They were singled out and watched closer than the other workers. "To a lot of us, long hair is simply a symbol of individual freedom and more natural feelings, but longhairs radiate something physical that they just haven’t got, and they don't like it."24

Harassment was not always the end of the conversation. Bans on long hair and suspension were common. In 1968 Captain Edward C. Lynch of Brooklyn's $78^{\text {th }}$ Police Precinct issued a notice to all policemen that "Long hair, sideburns, goatees, exaggerated mustaches do not fall into the definition of "neat and trim." The defintion for long hair

\footnotetext{
${ }^{23}$ Green, p. 219-220.

24 “Keep This Under Your Hat,” Newsweek, 26 July 1971, pp. 30-31.
} 
was no "shaggy overgrowth." One of the policemen remarked, "What it means is, we don't want anyone here looking like hippies., 25

Whether long hair or beards, the issue continued. A couple of months later Northwest Orient Airlines suspended twelve air freight employees for wearing "scraggly" beards and long sideburns. They were suspended after being given verbal warnings to remove their beards and shorten their sideburns. An airline spokesman said that there was no policy against beards or sideburns "as long as they're neat appearing. If they want to wear beards, fine, but not these scraggly things. ${ }^{26}$ Eventually the two sides came to a resolution and the employees were reinstated. The specifics on the resolution, however, depended on which airline spokesman was asked. A Northwest official at Kennedy airport announced they were allowed to go back to work pending a "new policy decision" at the company's Minneapolis headquarters. In Minneapolis, a different story was told. Mayo S. Brandjord, director of general services, said that the men had cleaned up whatever it was the company objected to and that no further action was pending. ${ }^{27}$

By September 1969, even women were getting shuffled into the mix. In Chicago, Deborah Renwick, an African-American stewardess was grounded by United Air Lines officials because her natural-hair style was too long. In response, groups of doctors, dentists, and civil rights advocates rallied to her cause. Her hair curled three inches from her head, which was a fashionable style at the time. She said that regulations called for short hair, and "I say my hair conforms." Notable American figures even became involved as the Reverend Jesse Jackson and the Reverend Calvin Morris of the Southern Christian Leadership Conference said in a telegram sent to the airline that they were

\footnotetext{
25 "Brooklyn Precinct Tells Men to Shun Hippie Look," New York Times, 15 July 1969, sec. 1, p. 33.

26 “'Airline Suspends 12 For 'Scraggly' Beards," New York Times, 19 August 1968, pg. 37.

${ }^{27}$ Airline Reinstates Five After A Hairy Dispute," New York Times, 20 August 1968, pg. 16.
} 
"disturbed by the abuse of...a black woman with a natural hair style in order to meet questionable requirements apparently dictated by advertising images." Other protestors that came to Renwick's aid were Dr. Andrew Thomas, president of the Cook County Physicians, and Dr. Albert Jackson, president of the Lincoln Dental Society. ${ }^{28}$

By the fall of 1970 , some men began to organize against the discriminatory policies many workplaces presented. Male civilian government workers formed Men's Lobe, an organization that was to fight for their right to wear sideburns down to the ear lobe if that's what they wanted. Kenneth T. Lyons, president of the National Association of Government Employees, announced the formation of the organization. The union leader said that Men's Lobe was formed "to combat the harassment of the 42,000 civilian technicians of the National Guard Bureau by various Guard officers. Many of the civilians had been ordered by many state adjunct generals to trim their sideburns or face dismissal. According to Lyons, “Technicians are civilians, not G.I.'s." He insisted that the men should be allowed to wear any hair style they wanted and added, "Lord knows the National Guard could use a little style., ${ }^{, 29}$

Another case involving an airline occurred in the winter of 1971 when Ozark Airlines banned beards, hair below the collar or over the ears, sideburns below the earlobes, and drooping mustaches as being "inconsistent with the public image Ozark is endeavoring to project." The ruling was being taken to arbitration by the Aircraft Mechanics Fraternal Association. ${ }^{30}$ Similarly, Pittsburgh police in Penn Hills were told by Chief E. E. Arnold to shave their conspicuous beards, mustaches, and sideburns. His

\footnotetext{
28 “'Natural' Hair Style Grounds Stewardess,” New York Times, 23 September 1969, pg. 93.

29 "Men's Lobe: Another Battle," New York Times, 10 October 1970, pg. 35.

${ }^{30}$ Richard W. Wertheim, "More Hair Now More Acceptable, but There Is a Cutoff Point," New York Times, 23 February 1971, pg. 32.
} 
reasoning was to convey "an impression of moderation, maturity, and settled confidence" to the public. ${ }^{31}$

Policies controlling the appearance of employees even led to walk-outs and strikes. In California, workers in a Diamond International Company plant initiated a strike after three employees were fired for refusing to cut their below-collar-length hair. The company's policy was that long-haired employees' hair might fall in their eyes or get caught in the machinery, causing accidents and interfering with the production of door jams, sills, and mouldings. The strike occurred one month after the employees were fired when a federal mediator failed to resolve the dispute. Mill officials believed that longer hair was a safety hazard and might cause accidents in the factory even though there had been no cases of such occurances up to that point. A spokesman for the striking members of Millman's Local 1495 agreed with the management over the safety concerns, but also believed that workers should be able to wear a hat, hairnet, or a short-haired wig if they wanted to keep their current appearance. John Biendara, the strikers' representative, gave the example of one rock band player with long hair was hired by the Diamond International mill when he applied wearing a wig. He eventually had to cut his hair after officials realized it was a wig. The mill members of the local wanted the three men reinstated, paid for their lost wages, and given fringe benefits. ${ }^{32}$

A couple years earlier in Britain, workers in an engineering plant in the Midlands organized a wildcat strike after a dispute over the length of an apprentice welder's hair. Twenty-year-old Graham Wadsworth had his hair down to his shoulders and managing

\footnotetext{
31 "Police Shaves Ordered," New York Times, 9 August 1972, pg. 21.

32 "Tangle Over Haircuts Touches Off Shutdown of California Factory," The Wall Street Journal, 24 August 1972,pg. 16.
} 
director of the York Trailer Company Fred W. Davies thought that it might make a bad impression on customers. Personnel manager Arthur A. Doughty said:

"Two weeks ago Mr. Davies noticed this lad with his long hair, and not so well groomed at that. It wasn't very decorative, and not so helpful to getting orders. I understand civil rights and all that, and the young do have different ideas. But we have to set a good image. So I went to him and said, 'Perhaps you could get a trim-up, something reasonable and realistic, mind you, not a short back and sides or a Yul Brynner.' But he wouldn't do it."

As a result, Davies saw Wadsworth with no sign of a trim and ordered him suspended with full pay until he cut his hair. According to Davies the hair needed to be at "a level more compatible with hygiene, safety, and dignity." After that point, 120 members of the Amalgamated engineering union walked out. They acted to see that "the lad's apprenticeship was protected." The resolution that was agreed upon: Wadsworth could keep his hair long but had to move to a plant down the road and stay out of the company cafeteria. He had an extra hour for lunch so that he could eat at home. The union was still unhappy and vowed to take the matter up at a works conference that was supposed to deal with larger issues of productivity. ${ }^{33}$

If it were not already hard enough for some people to get jobs, many were fired and deemed unemployable because of their hair length. A meter reader for Consolidated Edison Company was fired for refusing to cut his hair. Consolidated Edison said, "He refused to improve his appearance. We asked him to resign, he refused, so we had to relieve him.”34 The California Department of Human Resources began denying young men with long hair unemployment benefits arguing their appearance made them

\footnotetext{
${ }^{33}$ Anthony Lewis, "Length of Welder's Hair Sets Off a British Strike," New York Times, 15 April 1969, pg. 3.

34 “Con Ed Employee Dismissed Because of His Long Hair,” New York Times, 21 January 1969, sec. 1, p. 7.
} 
unemployable. On May 26, 1970 Department manager James Hammond had already refused checks to several unemployed young men. He said that he had surveyed nine hundred employers and found that only nineteen percent of them would hire men with hair below the bottom of their ears. ${ }^{35}$ At least in this case there seemed to be a concrete definition on what was being deemed excessively long hair.

On April 20, 1970, twenty-one year old Salt Lake City Maintainance Department Laborer Bruce Williams was fired for failure to adhere to a memorandum issued on the $2^{\text {nd }}$ of April. After being warned and suspended he was then fired. The memo read:

Due to the appearance of several of the employees in our department, I must remind you that all employees must be clean-shaven and have an acceptable haircut. ${ }^{36}$

Williams appealed the discharge and was rehired. One of the main arguments raised by Williams and his lawyer was that an "acceptable" haircut was never defined. Nobody ever explained to him or gave him an example of what the memo implied by an acceptable haircut. ${ }^{37}$ This had become a point of contention amongst the longhairs and their authority figures. There seemed to be no clear definition in most cases of what constituted a satisfactory hair length.

The problems and confusion that occurred by trying to define long hair had even worked its way into the halls of law enforcement. In New York City, a twenty-four year old patrolman by the name of John Bal claimed that he was being harassed within the department because of his long hair. The police regulation on hair length said that hair had to be neatly trimmed on the top. Bal's hair extended over the tops of his ears, but was not much longer in the back than some of the other patrolmen. He accused the

\footnotetext{
35 "Unemployment Check Denied to Mod Youths," New York Times, 27 May 1970, sec. 8 p. 50.

${ }^{36}$ William Timmins, "Long Hair in A Merit System: An Appeal from Utopia Avenue", 1972, p. 5.

${ }^{37}$ Ibid.
} 
department of having transferred him to a post in Central Park from his regular post in the $23^{\text {rd }}$ Precinct in East Harlem as part of the harassment. Bal said, "I do everything a cop should do. The length of my hair should have no bearing on how I am treated unless it interferes with my work." ${ }^{38}$

After a departmental hearing, Bal claimed that he was "treated like a criminal" and that nobody at the hearing would tell him what the charges against him were. The hearing, according to Bal, was to determine whether or not he had violated department rules by publicly discussing police policy. It is worthy to note that Patrolman Bal had received three commendations for heroism and exceptional police work within a span of two years. He did expect further action from the department since he had violated a direct order by talking to newsmen about the hearing. He said, "I have to do what I feel is right-I've got to bust out and be me." Bal wanted to help out other cops who felt the way that he did. He also wanted to remove the stigma that many young people had about the police that they were prone to violence and in some cases unjust: "Some people feel that you have to arm yourself against the police. I'm trying to bridge the gap." His new station in Central Park's Bethesda Fountain was a gathering place of many longhaired teen-agers, and was where his first news conference was held. Many of the young people who frequented that spot saw Bal as a hero, and some even waited outside the station for several hours to support him on the day of his hearing. ${ }^{39}$

Bal additionally noted that many other young men in the department wore their hair long enough to touch the collars of their shirts. "The issue goes deeper than my long hair. Most cops are afraid to speak up. They don't want to rock the boat. I'm fighting

\footnotetext{
38 “A Policeman's Tale Hangs by Hair," New York Times, 15 June 1970, pg. 26.

${ }^{39}$ Barbara Campbell, "Police Call in Long-Haired Patrolman," New York Times, 23 June 1970, pg. 47.
} 
for them." The issue along with hair length had a political agenda. Bal's departmental troubles apparently began after he had expressed his opinions against the war in Vietnam. ${ }^{40}$ After the hearing and Bal's statements, nearly all of the policemen assigned to the Central Park Precinct signed a petition, which called for his removal. The petition was signed by 127 officers charged that his behavior "is prejudicial to the good order and efficiency" of the precinct and department. In response, Bal said that many of the men who signed did so because they were afraid that if they did not, they would have been harassed as he was. A few of the officers in Central Park were very critical of Bal. "If you want to be a policeman you can't just go around and say you want to do your thing. You have to have discipline in the department." Others simply resented that Bal was regarded as a spokesman for the police. "He talks only for himself. We have groups that speak for us when we have something to say.” Bal pleaded not guilty to departmental charges of insubordination and took the stance that many of his longhaired brethren had been taking, "I have not knowingly broken any rules. I'm just challenging their interpretation. ${ }^{41}$

Many executives thought they had the answers to the long hair questions. Ronald Morgan, vice president of sales and marketing for Fanning Personnel said, "No beard to get hired, grow it back after you get the job....Companies have images they hire in. Once you perform, a lot of things are acceptable.” Pearl Meyer, vice president of research for Handy Associates, an executive search firm, gave an example of a displaced controller who was first interviewed with beard and long hair. The longer he looked for a job, the

\footnotetext{
${ }^{40}$ Ibid.

${ }^{41}$ Murray Schumach, "Long-Haired Policeman's Removal Is Urged by His Colleagues," New York Times, 9 August 1970,pg. 35 and "Long-Haired Patrolman Gets A Department Trial on Oct. 8," New York Times, 25 August 1970, pg. 19.
} 
more his confidence diminished and the shorter his hair became. She said, "I don't know anybody who got his job or lost it because of his attire but it could have a deep effect on whether he gets a new position. People can be a victim of unconscious bias. I think the pendulum went pretty far in one direction and now we're getting the reaction. I notice it in office furnishings as well as clothing and hair." But people were being dismissed and faced unemployment because of appearance outside of executive positions. One may or may not have been promoted in the corporate world due to his flowing locks, but in the working-class world, people were losing their jobs whether or not they had long hair before an interview or after they were hired. Paul Halvonik, a lawyer for a man who was fired and denied unemployment in California, made an interesting and appropriate point, "What would happen if a shoe store in Berkeley refused to hire a salesman with a crew cut because the students wouldn’t identify with him?"42

Harassment, suspensions, firings, strikes, and an overall clashing of ideals led many workplace incidents to climax at the judicial level. Many cases involving long hair were being heard by 1970 , and in many cases those with long hair were winning. In Montgomery, District Judge Frank M. Johnson, Jr. ordered the Alabama Highway Department to reinstate a highway engineer who had been fired due to his long hair. Mr. Smith had been dismissed, even though he had compiled a good service record within the department and had been promoted two years earlier. The employee said that his employers not only objected because he wore his hair "longer than what is considered average," but that he was also criticized "for expressing 'liberal' social and political

\footnotetext{
${ }^{42}$ Marylin Bender, “Corporate Look: Is It About To Change?," New York Times, 3 October 1971, pg. F3.
} 
views around the office." An office memorandum sent to the employees "linked long hair with inefficiency in work, poor reputation, and lack of ambition. ${ }^{, 43}$

Some cases even involved violence and long hair. In Buffalo, NY in September of 1970, three construction workers were ordered to pay one man \$1,368. Ralph Hobbs, Jack Taylor, and Glenn Detenbaeck grabbed twenty-year-old John Pierce off the street, dragged him into an alley, punched him in the face, and cut his long hair. After agreeing to pay for the injuries and the haircut, Judge Ann T. Mikoll dismissed the third-degree assault charges. ${ }^{44}$

Another situation where someone was awarded money in a hair case occurred in Hartford, Connecticut. The Grandway department-store chain was ordered by the Connecticut Commission on Human Rights to pay $\$ 1,536$ in back salary to Gregory Kuyumijian. Kuyumijian, a college student, had his hours cut back from twenty-four hours a week to eight hours a week, and he was also being given "dirty work." This was all as a result of the discrimination against the student because he grew a full beard and long hair. The commission cited rulings that men have the right to wear their hair the same length as women and ordered the department store to pay the difference of sixteen hours a week over a forty-eight-week period, where Kuyumijian worked for $\$ 2$ an hour. ${ }^{45}$

Some cases even made their way up to the State Supreme Court level. The New York State Supreme Court upheld the constitutional right of a public employee to determine the length of their hair, sideburns, mustache, and beard. A volunteer firefighter, John Hunt, filed suit against the Board of Fire Commissioners of the Massapequa Fire District. He was fired after one year of service by the Fire Department

\footnotetext{
43 "Judge Curbs Alabama on Ouster over Hair," New York Times, 18 November 1970, pg. 20.

44 “3 Who Cut Man's Hair Pay the Victim \$1,368," New York Times, 13 December 1970, pg. 82.

45 “'Long-Haired Man Wins Bias Case," New York Times, 25 August 1972, pg. 37.
} 
for violating rules which stated that hair was not to touch the collar of the shirt, sideburns could not extend below the ear, mustaches had to be neatly trimmed and not extend below the lower lip, and beards were not allowed. Justice Bernard Meyer ruled that Hunt had been illegally suspended and ordered his reinstatement. Justice Meyer also said that when Hunt promised to obey the rules of the department, "it must be read as requiring only that he comply with rules not in violation of his constitutional rights, and not as a waiver of such rights. ${ }^{\$ 4}$

Employees of government agencies were not immune to this type of discrimination. The Minneapolis Housing and Redevelopment Authority fired intern Jonathan Cain for having shoulder length hair. The Minneapolis Commission on Human Relations found that Cain was being discriminated against because of his sex. They observed that many females within the agency "wore their hair at the same or longer length." The agency was also ordered to pay $\$ 100$ in punitive damages to Cain. ${ }^{47} \mathrm{~A}$ different case involving the Federal Bureau of Investigation was heard by the Civil Service Commission. The ACLU won the case concerning Joseph Hamm, an FBI employee, who was dismissed on the ground that his hair was too long. Hamm had refused to trim his hair so that it did not touch his collar in the back or trim his sideburns no longer than the bottom of the ear lobe. The Civil Service Commission ordered that Hamm be reinstated. ${ }^{48}$

By the mid-1970s, issues over long hair were not as prevalent because lengthy hair on men was more common and in vogue. This does not mean, however, that lawsuits stemming from regulations placed in the mid to late sixties were non-existent.

\footnotetext{
46 "Hair-Style Case Is Won By Volunteer Fireman,” New York Times, 3 December 1971, pg. 43.

47 “"Panel Upholds Long Hair," New York Times, 5 October 1972, pg. 14.

48 “F.B.I. Loses Long-Hair Case," New York Times, 25 August 1972, pg. 42.
} 
In 1976 the Supreme Court ruled on the issue of long hair in the workplace. Patrolman Johnson took Suffolk County Police Commissioner Kelley to court to defend what Johnson called a violation of his Fourteenth Amendment rights. The County Police Department's hair-length regulations stated:

"Hair shall be neat, cleaned, trimmed, and present a groomed appearance. Hair will not touch the ears or the collar except in the closely cut hair on the back of the neck. Hair in the front will be groomed so that it does not fall below the band of properly worn headgear. The acceptability of a member's hair style will be based upon the criteria in this paragraph and not upon the style which he chooses to wear his hair."

That regulation was created in 1971. The New York Court of Appeals went on to decide that "choice of personal appearance is an ingredient of an individual's personal liberty" and is protected by the Fourteenth Amendment. It further held that the police department had "failed to make the slightest showing of the relationship between its regulation and the legitimate interest it sought to promote." On the basis of this reasoning it concluded that neither dismissal nor summary judgment in the District Court was appropriate, since the department "has the burden of establishing a genuine public need for the regulation."

The United States Supreme Court ruling did not come until five years later in 1976:

"The Suffolk County Police Department hair-length regulation was not an impermissible intrusion on employee's 'liberty' interest to choose their own hairstyle, since the county's choice of organizational structure, dress, and equipment is entitled to presumption of legislative validity, and regulation is not so irrational that it may be branded arbitrary."${ }^{, 50}$

\footnotetext{
${ }^{49}$ Kelley v. Johnson, 1 Individual Employment Rights Cases 55 (1976).

${ }^{50}$ Ibid.
} 
Mr. Justice Powell agreed with the Court's decision and stated:

"I concur in the opinion of the Court and write to make clear that, contrary to the concern expressed in the dissent, I find no negative implication in the opinion with respect to a liberty interest within the Fourteenth Amendment as to matters of personal appearance. When the State has an interest in regulating one's personal appearance, as it certainly does in this case, there must be a weighing of the degree of infringement of the individual's liberty interest against the need for the regulation. This process of analysis justifies the application of a reasonable regulation to a uniformed police force that would be an impermissible intrusion upon liberty in a different context.",51

In a dissenting opinion Mr. Justice Marshall and Mr. Justice Brennan stated:

"As the Court recognizes, the Fourteenth Amendment's guarantee against the deprivation of liberty 'protects substantive aspects of liberty against unconstitutional restrictions by the State.' And we have observed that 'liberty under law extends to the full range of conduct which the individual is free to pursue.' It seems to me manifest that that 'full range of conduct' must encompass one's interest in dressing according to his own taste. An individual's personal appearance may reflect, sustain, and nourish his personality and may well be used as a means of expressing his attitude and lifestyle. In taking control over a citizen's personal appearance, the government forces him to sacrifice substantial elements of his integrity and identity as well." 52

There were obviously cases that did not come out in favor of the long-haired employees. Justice William Rehnquist, an extremely right-wing member of the Court, and Justice Warren Burger, a conservative with a strict-constructionist reading of the Constitution, both agreed that patrolman Johnson's right to wear his hair long was not protected under the Fourteenth Amendment. Justice Thurgood Marshall and Justice

\footnotetext{
${ }^{51}$ Doug Linder, “U.S. Supreme Court: Kelley v. Johnson, 425 U.S. 238 (1976),” Exploring Constitutional Law. 2006. <http://www.law.umkc.edu/faculty/projects/ftrials/conlaw/KelleyvJohnson.html $>2006$.

${ }^{52}$ Ibid.
} 
William Brennan, both liberal supporters of individual rights, dissented and agreed that the definition of personal liberty included people's right to look the way they want to look. The controversy over hair extended throughout society and lines were drawn in places of employment across the nation. Every city and town had their own biases and regulations to control the personal appearance of its employees. 


\section{Across the Universe: How Popular Culture Helped to Lengthen Hair}

For as long as they have existed in American popular culture, musicians, movie stars, and athletes have been heroes and role models to young men and boys across the nation. Whether the youth of the nation were admiring Elvis, James Dean, or Joe DiMaggio, celebrities represented, and still do today, everything boys and men wanted to be. They wanted to look like, talk like, and act like them in every way possible. The same thing occurred in the sixties when long-haired musicians, movies about men with uncontrollable hair and attitudes, and athletes with hair flowing out of their helmets and hats made their way into popular culture. The influence that these public figures made on youth culture in general and, more specifically, on the long hair craze is undeniable.

Many people argue that the long hair trend was popularized and even began with the Beatles. Possibly the most influential music group in the history of rock music, the Beatles influenced everything from new music styles and production methods to clothing and haircuts to attitudes and ideals. They were right in the middle of the sixties revolution. "The Sixties saw a revolution among youth—not just concentrating in small pockets or classes, but a revolution in a whole way of thinking. The youth got it first and the next generation second. The Beatles were part of the revolution, which is really an evolution, and is continuing. We were all on this ship - a ship going to discover the New World. And The Beatles were in the crow's nest."

They popularized Beatle boots in their early days and later military fatigues and vibrant, psychedelic colored clothing in their Sgt. Pepper days. From their first appearance in America to their final days as a group, the Beatles went from music superstardom where they held the top 5 singles on Billboard's singles chart with "Can't

\footnotetext{
${ }^{1}$ The Beatles, The Beatles Anthology, (Italy: Apple Corps Ltd., 2000), back cover flap.
} 
But Me Love" at \#1 followed by "Twist \& Shout," "She Loves You," "I Want To Hold Your Hand," and "Please Please Me" in April of 1964 to multimedia popular culture idols with the success of their movie ventures A Hard Day's Night, Help!, and Yellow Submarine. Their impact on the culture of the American youth was very tangible and it started with their hair. According to George Harrison, their first consideration for the moptop look came as a result of a suggestion of two of their friends:

"I remember we went to the swimming baths once and my hair was down from the water and they said, 'No, leave it, it's good.' I didn't have my Vaseline anyway, and I was thinking, 'Well, these people are cool—if they think it's good, I'll leave it like this.' They gave me that confidence and when it dried off it dried naturally down, which later became 'the look'. Before that, as a rocker, I wore my hair back; though it would never go back without a fight-it goes forward when I wash it. (It just grows into a Beatle cut!)"2

Paul McCartney explained why they all wore their hair down for the first time, "We tried our 'Beatle' hairstyle in Hamburg this time. It was part of trying to pull people in:

'Come in. We are very good rock'n'roll!"’3 Finally, on a trip to Paris Lennon and

McCartney both decided to get their hair cut into the moptop form after a meeting with famous photographer Jürgen Vollmer. John Lennon recalled:

"Jürgen also had bell-bottom trousers, but we thought that would be considered too queer back in Liverpool. We didn't want to appear feminine or anything like that, because our audience in Liverpool still had a lot of fellas. (We were playing rock, dressed in leather, though Paul's ballads were bringing in more and more girls.) Anyway, Jürgen had a flattened-down hairstyle with a fringe in the front, which we rather took to. We went over to his place and there and then he cut-hacked would be a better word-our hair into the same style."4

\footnotetext{
${ }^{2}$ Ibid, p. 56.

${ }^{3}$ Ibid. p. 56

${ }^{4}$ Ibid, p. 64.
} 
McCartney similarly recalled the impact that Vollmer made on them:

"He had his hair Mod-style. We said, 'Would you do our hair like yours?' We're on holiday — what the hell! We're buying capes and pantaloons, throwing caution to the wind. He said, 'No, boys, no. I like you as Rocker; you look great.' But we begged him enough so he said 'all right'....WE sat down in his hotel and he just got it—-the 'Beatle' cut!"’

They went back to Liverpool where the new look caught on and according to McCartney, "Everyone thought we had started it, so it became 'the Beatle hairdo.' Lennon also claimed that they were guilty with going along with the trends, but realized that they made trends popular. He also admitted that he was embarrassed when they had to come to the United States and say that they were from Britain, because the British style was "square and sorry." It became a goal of theirs to change Britain's image and as a result they changed hairstyles and clothes in both Britain and the U.S. They used other methods to get themselves noticed in the U.S. before they came over that simultaneously helped to spread the new hairstyle. ${ }^{6}$ McCartney remembers, "I think the money was mainly spent in LA getting people like Janet Leigh to wear Beatle wigs and be photographed in them, which started it all. Once a film star did that, it could get syndicated all across America: 'Look at this funny picture; Janet Leigh in this wacko wig — the "moptop" wig.' And so the whole 'moptop' thing started there. And it did get us noticed."

The group realized the troubles that many youths faced my emulating them. Lennon never forgot what it was like before they became the all-powerful Beatles:

\footnotetext{
${ }^{5}$ Ibid. p. 64

${ }^{6}$ Ibid. p. 64

${ }^{7}$ Ibid, p. 116.
} 
"Once, we went into a restaurant and nearly got thrown out for looking like we looked, until they saw who it was:

'What do you want?' the head waiter said. 'We've come to bloody eat, that's what we want,' we said. Then the owner spotted us and said, 'Ah, a table, sir, over here, sir.' It took me back to when I was nineteen and I couldn't get anywhere without being stared at or remarked about. It's only since I've been a Beatle that people have said, 'Oh, wonderful, come in, come in,' and I've forgotten a bit about what they're really thinking. They see the shining star, but when there's no glow about you, they see only the clothes and the haircut again. We weren't as open and truthful when we didn't have the power to be. We had to take it easy. We had to shorten our hair to leave Liverpool....We had to compromise....We had to falsify a bit, even if we didn't realize it at the time."

Cinema in the late sixties greatly expressed youth cultural ideals and movements and moved certain issues to the forefront. The movie industry in the sixties, however, was going through a transition period. By the 1960s Hollywood's Golden Age was coming to an end and movies were not the central part of life in American culture they once had been. The studio system was dead and the audiences had shrunk. It was also the beginning of the era of individual packaging of film productions and more pictures were being shot on location away from Hollywood. Some believe that if it had not been for the regular production of TV movies, Hollywood might have been knocked out of the business entirely. ${ }^{9}$

Films were beginning to reflect the profound changes in the nation's psyche.

Producers of The Pawnbroker received permission to include a scene of a woman naked from the waist up. The next year, Mike Nichols was allowed to include such foul

\footnotetext{
${ }^{8}$ Ibid, p. 103.

${ }^{9}$ Robert J Bresler, "The Death of Hollywood's Golden Age and the Changing American Character," USA Today Magazine (March 1997, Vol. 125 Issue 2622) pp. 64-67.
} 
language uttered by Elizabeth Taylor in Who's Afraid of Virginia Woolf? ${ }^{10}$ as "And I'm gonna howl it out, and I'm not gonna give a damn what I do and I'm gonna make the biggest god-damn explosion you've ever heard." ${ }^{, 11}$ By 1968, when Jack Valenti succeeded Eric Johnston as head of the Motion Picture Association, the Rating System replaced the censorship associated with the Production Code. ${ }^{12}$

The motion picture industry along with the rest of the nation found itself in a new era of cultural freedom for which there was no script. There were some early and hopeful indications that this would usher in a new period of boldness and creativity. One example was John Schlesinger's Midnight Cowboy, a film about the desperate world of a male hustler. Hollywood then turned to a new cynicism. This cynicism rejected everything the old Hollywood mythologized: America, the family, the military, the business community, and organized religion. The Graduate (1967) first marked this new attitude. In the movie Dustin Hoffman returns from college to an empty, materialistic, and sexually insatiable culture from which he and Katharine Ross happily escape. To where and to what, no one seems to care. The Graduate, along with movies like Bob and Carol and Ted and Alice, and Goodbye, Columbus all satirized the hypocrisy of middleclass values. In the same year, director Arthur Penn in "Bonnie and Clyde" idealized two psychopathic killers played by Warren Beatty and Faye Dunaway as sexually attractive social rebels alienated by society. Other such movies that glorified lawlessness were The

\footnotetext{
${ }^{10}$ Seth Cagin and Philip Dray, Born to be Wild: Hollywood and the Sixties Generation, (Boca Raton, Fl: Coyote, 1994).

${ }^{11}$ Who's Afraid of Virginia Woolf, dir. Mike Nichols, Warner Bros. Pictures presents a Chenault Inc. Production, (Universal City, CA: Warner Bros, 1966).

${ }^{12}$ Op. cit. Born to be Wild.
} 
Dirty Dozen, Cool Hand Luke, Butch Cassidy and the Sundance Kid, and, especially, Easy Rider, which will be discussed more depth. ${ }^{13}$

One movie that took many chances by pushing the boundaries of Old Hollywood and pushed upon its audience a clear countercultural point of view was Medium Cool. The movie is based in Chicago in 1968 around John Cassellis, a TV cameraman. Throughout the movie the fictitious plot of the TV cameraman, his romance, his job, his girl and her son are mixed in with actual footage of the riots during the 1968 Democratic National Convention. Cassellis interacts with a variety of people, from the military to protestors to black militants to other members of the media. The main point of the movie is to show the desensitization of violence in the media and the violence of the society in which they lived. Police were violent towards protestors and vice versa, blacks were violent towards whites and vice versa, and everyday violence from car wrecks and murders was top priority for news corporations. The movie, however, ends up giving excellent insight to what rebellious, countercultural, and anti-establishment culture was like.

There were two movies made in the sixties (both in 1969) that specifically expressed the problems faced by the youth of America's cultural choices were Alice's Restaurant and Easy Rider. In Alice's Restaurant, Arlo Guthrie is thrown out of a restaurant through a plate-glass window by three young brutes who object to his long hair. Sitting along the curb and bleeding, he is then arrested for disturbing the peace. After he protests his innocence, the police look at him and his long hair and put him in jail.

\footnotetext{
${ }^{13}$ Ibid.
} 
Easy Rider was a creation of actors Dennis Hopper and Peter Fonda. It started off with the two of them selling some sort of unidentified drug to a man in a Rolls Royce outside of an airplane landing strip. The money they received was placed in a plastic tube which Peter Fonda's character placed in the gas tank of his motorcycle. The characters then revealed their plan: to ride cross-country from Mexico to Mardi Gras and then onto Florida where they will retire, rich from their recent drug deal. Along the way they encountered a hitch-hiker, a hippie commune, an ACLU lawyer from a small southern town (played by Jack Nicholson), police officers, rednecks, and prostitutes. Just outside of New Orleans they stop at a roadside café. Several people in the café make scathing remarks about their appearance. The waitress does not serve them and two local police officers joke about how they should arrest the "animals". After they leave having not been waited on, they camp for the night just off the road nearby. During the night they are attacked and Jack Nicholson's character is murdered. A few days later, Hopper and Fonda's characters are shot while riding their motorcycles and killed.

The portrayal of the kind of people they encountered was not hidden in context. They hit the viewer right over the head with their message. The hippies they met in the commune were eccentric, nice, and they were all the same. The police officers and most of the southern men they encountered were racist, intolerant, and all the same. Hopper and Fonda depicted two rebels who rode against conformity. Establishment was their enemy, from rednecks to the government to hippies on a commune. The irony is that the same establishment and conformity they were running from was the same one that got them in the end. It got them when the rednecks in the pickup truck shot them. At the same time, however, they had already become what they rebelled against when they sold 
out their ideals by stuffing their gas tanks with money from the establishment. Another point that Easy Rider made was that no rebels in a conformist society are safe. It was not just the bike freaks who got in trouble when they challenged the establishment, but even George the ACLU lawyer got brutally beaten and killed holding the same ideals. At one point in the film George and Billy (Hopper's character) were having a discussion about freedom and Billy said, "What the hell is wrong with freedom? That's what it's all about." George responded with what could be considered the mantra of the movie:

“...But talkin' about it and bein' it, that's two different things. I mean, it's real hard to be free when you are bought and sold in the marketplace. Of course, don't ever tell anybody that they're not free, 'cause then they're gonna get real busy killin' and maimin' to prove to you that they are. Oh, yeah, they're gonna talk to you, and talk to you, and talk to you about individual freedom. But they see a free individual, it's gonna scare 'em.",

After seeing Alice's Restaurant and Easy Rider, one man in a letter to the editor began to make some observations about the society around him. Sitting in a cab he and the driver saw a long-haired teen-age boy cross the street. He wore bell-bottoms, an open-necked shirt, and his hair fell below his shoulders. The driver said, "You see that? Boy, if I could get outa this cab right now, I'd go up and whip that kid and shave his skull naked." Later, the same man picked up two hitchhikers on his way home. They too wore long hair and had beards. He learned that they were hitchhiking across America as they were students at the University of California Santa Barbara. They stopped in a café where the waitress was "hardly civil to us." According to the hitchhikers, while just outside of New Orleans they had "stopped at a roadside café for coffee. Inside, they were completely ignored by the waitress. Two parties of teen-age boys began a barrage of

\footnotetext{
${ }^{14}$ Easy Rider, dir. Dennis Hopper, (Metro-Goldwyn-Mayer (MGM) Present a Florin Production, (Universal City, CA: MGM, 1969).
} 
caustic remarks. Two local policemen entered the care, approached the travelers, yanked them out of their chairs, threw them against the counter and searched them. Finding a pocketknife on one of them, the police put the two hitchhikers in jail overnight for illegal possession of a dangerous weapon." 15

In response to that letter one citizen expressed an opinion which was common at that time:

“...the long-haired unkempt young things who so arouse the public are a different phenomenon entirely. They are not individualists. They are wearing a uniform (albeit a sloppy one). Their reason for wearing it appears, to the man in the street, to be to express contempt for their parents, their elders, their homes, their country. Their dirtiness and contrived ugliness seem to bespeak a lack of respect for themselves, as well as for others." 16

The writer has contradicted herself. It is true that at that point, the young people she spoke of were most likely not individualists, at least not as far as their appearance was concerned. Long hair, beards, bell-bottoms, and love beads were all popular trends by 1969. Her paradoxical opinion occurs when she claims that the non-individualists looked the way they did because they were expressing a common ideology. While the young men who started out wearing long hair did have a political and social agenda, by 1969 it was impossible for anyone to tell who was expressing an opinion and who simply wanted to look like John Lennon.

Just as Hopper and Fonda rode their motorcycles across the country in Easy Rider, two longhaired writers for the New York Times rode their motorcycles from Pittsburgh to the Badlands of South Dakota and even as far west as Wyoming. Through

\footnotetext{
${ }^{15}$ Tom Andrews, "Movie Mailbag: Why Do They Hate Long Hair?" New York Times, 2 November 1969, sec. D, p. 13.

${ }^{16}$ Joyce P. Davis, “Movie Mailbag: Just Too Much,” New York Times, 30 November 1969, sec. D, p. 6.
} 
much of their trip they experienced a relaxed and friendly atmosphere, but through the middle parts of the country the two authors reported "impolite curiosity and studied neglect." Their most enjoyable times came when they took pleasure in the simple friendship and sense of community they found among people their own age. The two bikers did experience some scary encounters, however. In Wyoming, they stopped at a gas station and encountered "two cowboys, in boots, ten-gallon hats and all." One of them waved a pair of shears at them and said, "You boys looking for a barber? I mean, you want a haircut? We're sheepshearers, and we sure could use some practice. You guys camping around here, by any chance?" The writers left quickly and later stumbled upon some "equally hairy travelers" who told them that while they were in a bar in the same town that the bartender warned them to steer clear of "two sheepshearers who'll cut your hair off." He also suggested that they leave town quickly. According to the authors, however, "The occasional unpleasant treatment our appearance inspired paled by comparison" to the sights that they saw and decent people that they met. ${ }^{17}$

Athletes also had a major impact on the spread of many fashions and fads that the youth of America admired. For instance, one of the most innovative players the National Basketball Association had ever seen looked like just another longhair. "Pistol" Pete Maravich's appearance was as distinctive as his style of play. He had long hair and wore floppy white socks on the court. After each game when he played in Atlanta-whether they won or lost_- "crowds of excited teen-agers and embarrassed-looking adults surge around the exits waiting for the six-foot-five-inch star. Sometimes they just ask for his

\footnotetext{
${ }^{17}$ Andrew Gordon and David Stock, “A Long-Haired Safari Across Middle America,” New York Times, 4 October 1970, p. 364.
} 
autograph, but occasionally girls rush at him and grab at his long hair. Often he has to call on security guards to help him escape."

Basketball was not the only sport where players like "Pistol" Pete were present. Ken "Hawk" Harrelson, a first baseman and outfielder for the Cleveland Indians, was known in the city he played for his long, flowing hair. He ran into a dilemma, though. His manager Alvin Dark told him to either lighten his head or they would lighten his paycheck. Harrelson cut his locks and when asked why said, "Alvin said you get your head to a barbershop or be fined, and I said all right if it was just going to be $\$ 100$ fine, I would have taken it and kept my hair. He didn't say how much the fine would be, but he was speaking in a $\$ 1,000$ tone." A couple of Cleveland fans had their own opinions on the matter. One woman wrote to Harrelson, "I don't see anything wrong with the way you wear your hair. I like it that way. And what does hair have to do with playing ball? Joe Namath of the Jets has long hair, but I think you look better than he does." Another fan sent a letter to Dark that stated, "Now we can once again watch men, not girls, play baseball. If the beautiful Hawk isn't happy with your decision, he can always get a job in a beauty salon, modeling hair, leather coats, red shirts, plaid slacks, and orchid-tinted eyelids." 19

Many coaches across the nation were responding to long hair the same way Dark did. Coach Payton Jordan at Stanford and Coach Dee Andros at Oregon State both dismissed athletes from their teams for having long hair and beards. ${ }^{20}$ Five coaches at Coe College in Iowa resigned over long hair and the grooming code. The football,

\footnotetext{
${ }^{18}$ Tom Herman, “A Long-Haired Rookie Makes Losing Season A Box-Office Victory,” New York Times, 25 March 1971, sec. C, p. 1.

${ }^{19}$ Murray Chass, "Indian Fans Divided over Harrelson's Shorn Locks," New York Times, 3 May 1970, p. 47.

${ }^{20}$ William N. Wallace, “Sports of the Times: Hair,” New York Times, 9 July 1970, p. 45.
} 
basketball, baseball, track, and wrestling coaches all resigned when the Student Senate inquired about possible discrimination against six Coe College athletes. According to a grooming code outlined by the coaches, the athletes' hair and beard styles were of an unacceptable nature. The coaches were asked by the President of the college to come up with a modified code, but they refused. ${ }^{21}$ Possibly the most famous coach of all-time, Vince Lombardi, had strict grooming rules with the Redskins and told a mustached Trenton Jackson that he could run faster "without that thing on your lip." When asked why coaches do not like long hair, Dee Andros responded that it is neither neat nor athletic. Ara Parseghian of Notre Dame said, "The fad started with hippies. It [hair] gives an empathy for the direct opposite of what we strive for in football. The hippie movement is geared to shiftlessness. You won't find a lazy person the football field.” One Californian coach offered his theory as to why coaches may be preoccupied with players' hair. Jack Scott suggested that many coaches feel the way they do as a subconscious defense against latent homosexuality. ${ }^{22}$

Not all coaches felt the way that Lombardi and Parseghian did. Multiple World Series winner Coach Casey Stengel defended athletes with longer than standard hair. Stengel began to defend the players after being asked to comment on Joe Namath of the New York Jets and Joe Pepitone a former New York Yankee star, both of whom had long hair. Stengel replied, "I don't care if they have hair to here [the middle of the back]. I would keep that man [Namath] and Pepitone as long as he played good.” He was then asked whether he had ever had a player who gave him as much trouble as Namath seems

\footnotetext{
21 “Coaching Staff Resigns in a Dispute over Hair,” New York Times, 12 December 1970, p. 42.

${ }^{22}$ Op. cit., Wallace, "Hair".
} 
to give his coaches and Stengel answered, "How many times has he been lousy on the field? ${ }^{, 23}$

The fact is Namath was not lousy on the field. He led the Jets to a Super Bowl III victory, is the Jets all-time leader in passing yards with 27,057, and was named to the Hall of Fame in 1985. But much of the talk around the nation during the sixties about Namath had little or nothing to do with his playing ability, but with his long hair and flashy style. His nickname was Broadway Joe and would often be seen wearing fur coats. Namath responded to critics who said that celebrities and athletes with long hair were a bad influence on children with, "That's ridiculous. Who tells the little ones it's a bad influence? The parents do." ${ }^{24}$ In his autobiography, Namath reflected on the controversy over his long hair and facial hairstyles, "The Only Perfect Man who ever lived had a beard and long hair and didn't wear shoes and slept in barns and didn't hold a regular job and never put on a tie. I'm not comparing myself to Him-I'm in enough trouble trying to stack up against Bart Starr-but I'm just saying that you don't judge a man by the way he cuts his hair., 25

Celebrity fashion influences society so much that a six-year-old boy can have a defining influence on culture. John F. Kennedy, Jr. let his hair grow and by 1967 his longer-than-average sideburns were a topic of discussion. His mophead hairstyle prompted criticism while he lived in the White House. His full head of hair became a national status symbol for any pre-school male. Even though he is only six, his style changes were significant. He began to look more like a Beatle with a moptop than an

\footnotetext{
23 “Casey Stengel's Cantata Gives City Hall a Tip: Don't Fight Long-Hairs,” New York Times, 8 August 1970, p. 16.

${ }^{24}$ Robert Lipsyte, "Sports of the Times: Hair," New York Times, 11 November 1968, p. 65.

${ }^{25}$ Robert Lipsyte, "Sports of the Times: Two New Books," New York Times, 1 November 1969, p. 41.
} 
English schoolboy with a head of well-groomed, short hair. From Paris to New York young boys were styling their hair longer and sideburns were growing. Jerry Spallina, the owner of a Madison Avenue barbershop said, "Now when I get through, the customer looks like he needed a haircut three or four weeks ago." John-John's hairstyle became his own. It was synonymous with his name. But before that it started out in connotation with the British royal family and was called the English cut. Sam Michael of Michael's, a children's haircutting salon on Madison Avenue, noted, "People of English background, let's say the Nordic people, never had the crew cut." Years earlier, mothers referred to the look as the Prince Charles. That style, however, consisted of shorter bangs and a part to the side with shortened sideburns. The John-John consisted of thick hair with bangs going into the eyes. It was very much in the Mod style or in the style of The Beatles. Paul Molé owned a barbershop on Lexington Avenue in New York. He observed that there was becoming no difference between little boy's and young men's hair. ${ }^{26}$

For as much influence as celebrities had on popular culture, they were not always immune to the same criticisms that other young people were. Joe Namath had to undergo much scrutiny by coaches and fans alike because of his hair. The Beatles were constantly seen as bad influences by parents and other figures in positions of authority. Dave Brubeck, a famous jazz pianist, had to cancel part of his tour in Singapore because his hair was too long. He was not the first. Joe Cocker and Cliff Richards were also banned from playing in Singapore for the same reasons, and Cat Stevens was almost banned. ${ }^{27}$ The rock and roll, long hair, pop cultural phenomenon lifestyle affected all areas of youth society. For instance, an army reservist from New York was ordered by his commanding

\footnotetext{
${ }^{26}$ Marylin Bender, “Sideburns Key to John-John Haircut," New York Times, 10 January 1969, p. 47.

${ }^{27}$ James F. Clarity, "Notes on People: Lansky Resigned," New York Times, 14 September 1972, p. 53.
} 
general, Major General J. W. Kaine of the $77^{\text {th }}$ Army Reserve Command at Fort Totten, Queens, to cut his hair. Harold Raderman contended that he had to keep his hair at shoulder length in order to keep his job as a rock and roll talent scout. Any time he reported for duty with his hair long, he was counted as absent. After finding out that he would be called to active duty for being absent at reserve drills too many times, Raderman took the army to court. ${ }^{28}$ The antiestablishment attitude that celebrities began to celebrate, both in their attitudes and appearance and in their work, caused many people of the older generation to become scared and to feel that new music and movies were bad influences. What it did do was popularize long hair and, in some cases, the attitudes that came along with countercultural appearances. Long hair became acceptable to a large proportion of the youth in America not because it was the hairstyle of the New Left and anti-war protesters, but because it was the same kind of hair that John Lennon or Joe Namath or Peter Fonda had.

\footnotetext{
28 “Army Hiar Dispute Goes To High Court,” New York Times, 12 August 1969, p. 24.
} 


\section{The End: Barbers and the Future for Long Hair}

As previously discussed, the long hair issue had infiltrated all areas of society.

From school to the workplace to the popular culture that helped to influence the changes, young men set in motion a cultural wonder that touched areas of everyday life around the country. Young longhairs, their parents and bosses, or simply the everyday man in the street had some sort of opinion on the touchy subject, and they were most likely willing to speak their minds. The cultural and social ramifications that the controversy over long hair wrought were not the end of the discussion. The one area of society that the trend of long hair on young men had the greatest impact is on the one yet to be discussed. The one place in the general public that hairstyle fads had a chance to seriously affect everyday life and the standard of living was on barbers. Throughout the debate over long hair lingered the economic consequences that the issue could have on the barbering world.

In 1967 at the $48^{\text {th }}$ Annual State Convention in Bluffs, Iowa, a group of barbers who attended came to the consensus that young men across the nation were becoming "long hairs." They made a distinction, however, between what they called regular male long hairs and the droopy "long-long hairs." One barber pointed out that most of the "long-long hair" types were either most likely found in larger cities or members of a rock and roll group. Clyde Kenyon of Des Moines, IA was the director of the state Barber Division and president of the National Association of Barber Examiners. He was quoted as saying, "Barbers don't do much shaving anymore....coloring and styling is the thing." He attributed the development of the long hair trend to European hairstylists who came to America and tried out the hairstyle in some American shops. Barbers began to claim that 
long haired boys cut out the volume of business. Barber Jack Berger explained, "They don't come in as often and when they do, they're very particular....they want it full here and trimmed there." The number of teen-age customers accounted for so much of business that the slack caused from longer hair forced many shops to began to raise the price of a haircut. One barber predicted, "Within the next ten years, many men will be spending as much or more on their coiffure than women."1 According to a 1968 National Education Television report, men were at that point spending four hundred million dollars a year on grooming products compared to sixty million dollars in $1963 .^{2}$ According to this evidence, men were becoming more and more reliant on hair products as their hair grew longer. This shifted them further away from shorter, more manageable lengths into hair styles that required more time and maintenance.

As a result of the growing trend towards longer hair, some local barbershops began to take more radical steps. Local 415 of the barber's union cooperated with the Turner Advertising Company in 1968 to finance more than twenty-five billboards that pictured a long-haired male wearing a black turtleneck and love beads. Beside his face the billboard read: "BEAUTIFY AMERICA: get a haircut." Members of Local 689 in Washtenaw, Michigan apparently received positive response to their billboards that featured the same "hippie" and eight more were erected near Amarillo, Texas. ${ }^{3}$

Barbers around the country were forced to take some sort of action, however, if they wanted to keep up their profits and, in some cases, keep their shops open. The Journeyman Barber's International Union set up an On the Job Training program through

\footnotetext{
1 "The Trend to Longer Styled Hair Is an Outgrowth of Butch and Crew," Journeyman Barber, Hairdresser, and Cosmotologist 63 (March 1967): 27.

${ }^{2}$ Bernice Golden, "New Grooming Aids Invade Men's Market," Journeyman Barber, Hairdresser, and Cosmotologist 64 (February 1968): 24-25.

3 "International News," Journeyman Barber, Hairdresser, and Cosmotologist, 64 (February 1968): 38.
} 
the United States Department of Labor in 1967. The On the Job Training taught barbers the following: salesmanship, shear blending, hair straightening, hair coloring, hairpiece fitting, and contour razor cutting. Shear blending, hair straightening, hair coloring, and contour razor cutting were all techniques that were becoming more popular as men began wanting their hair styled rather than cut. All of those techniques were not necessarily popular practices by local barbers. The On the Job Training also provided barbers with a styling tool kit. After the program was finished, reports came in that indicated that those who put the training to use increased their shop income over two thousand dollars a year. ${ }^{4}$ Barbershops began to change in response. Barbers were now hairstylists. No longer was it two dollars for a shave and a haircut. Now prices ranged from six to one hundred dollars. Barbers began to remodel. New shops began to look more and more like beauty parlors everyday. ${ }^{5}$

Changing was vital to the survival of the local barbershop. Many youths claimed that would be more likely to go see a barber if they knew how to style their long hair. They felt that barbers were inept when it came to trimming their long hair. The GQ

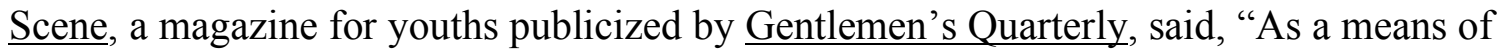
protection, many young men have put their haircutting into the hands of friends rather than risk a hacking from an unsympathetic barber." One barber college manager admitted that older barbers who refused to adjust to the wants of the long-haired men were being particularly hard hit: "Hair stylists who give razor cuts, heat-set the hair, straighten it, curl it and even dye it can and do compensate for business lost to long hairs." Some barbers who were more stuck in their ways simply waited for the times and

\footnotetext{
${ }^{4}$ Victor Hood, "OJT Ends-New Program Under Way," Journeyman Barber, Hairdresser, and Cosmotologist, 63 (April 1967): 4.

5 “Longer Hair Not Necessarily Hippie,” Time, October 1967, p. 46.
} 
styles to change. One shop in Greenwich Village put a sign in the window of their usually empty shop that read: "We specialize in crew cuts."

The fixation with long hair seemed to cause even more problems for barbers who worked in shops at or near college campuses. Joe Direktor, a barber near Columbia University in New York, noted, "This used to be a good growing business. Now it's not. Long hair did it." Around the country barbers were being laid off and some shops even considered closing. Robert Blumenthal, a junior at Columbia University, illustrated why. "I rarely go to a barber - perhaps only three times a year. I used to go every month. Now I'm more likely to ask a girlfriend to trim my hair." Another student also claimed that he had only had two haircuts in the past year. One owner of a three-chaired barbershop near New York University's campus in Greenwich Village blamed his troubles on The Beatles. David Oksenhorn claimed, "Before they came along I had two other barbers working with me. Now I run the place all by myself. What can you do when fellows only get their hair cut once in six months?"”

It was not just college campuses in large cities that felt the wrath of "hair power." College campuses located in smaller more rural areas were affected as well. One such campus was West Virginia University in Morgantown, West Virginia. Barbers in Morgantown saw a drastic drop in college customers starting in January 1969. A barber, who happened to see an old customer of his walk by said, "See that college student there, well, he used to come in here on the average of every two weeks last semester. He hasn't been in here since the beginning of this semester and see how long he's wearing his hair. I think the majority of students on this campus have gone hippie!" When asked if he

\footnotetext{
${ }^{6}$ Clarence Newman, "The Barber Pall: Long Hair Hurts Clipping Business,” The Wall Street Journal, 23 September 1966, p. 1.

${ }^{7}$ Ibid.
} 
thought the drop off in haircuts was because the price had been raised 25 cents from $\$ 2.00$ to $\$ 2.25$, he said that he did not think so because it was only 25 cents and there were other barbers around the area that charged $\$ 2.50$. Several of the male students claimed that the reason they were not going to get haircuts was because, "when they request only a slight trim on their long hair, the barbers go 'wild' and take advantage of all that long hair at their immediate disposal. Instead of a slight trim, the students in

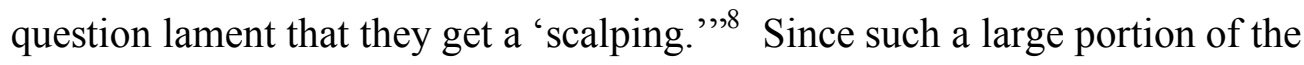
Morgantown population during the school year is as a result of college students, one can only imagine the hit that local barbers who relied on the college business took.

Was long hair the problem or was it simply something to blame in a time when change was everywhere and lines were being drawn? Did parents, teachers, principals, bosses, and neighbors really hate long hair or was it what long hair represented to them? George Washington, Thomas Jefferson, Benjamin Franklin, and many more of our nation's founding fathers wore long hair and they too were revolutionaries. Fear regulated feelings on long hair and what it represented to those who spoke out against long hair. Their claim was that it was dirty and looked unpleasant. It was unrespectful, irresponsible, and lazy. Work ethic had flown out the window and longhaired hippies were living in communes and mooching off of decent working folk. Fear is what ruled the day: fear of communism, fear of a changing society, fear of violence, fear of sexuality and racial tensions. The tension surrounding long hair came out of fear. For example, the Illinois Secretary of State was ordered by a federal court to discard the ballot for the upcoming constitutional convention and reorder the ballot through the use of a lottery. The ballot, the court ruled, was discriminatory. Illinois Secretary of State

\footnotetext{
8 “Barbers Taking 'Bad Hit’ As Hair Gets Longer...," Daily Athenaeum, 19 February 1969, p. 2.
} 
Paul Powell claimed that he would disregard the court order and deemed the decision to be "an effort by long-haired hippie Communists to get on the ballot. This is a move to destroy the two-party system. I favor the two-party system. I am carrying out what has been going on for fifty years and I will continue to do so."9

Young people of the nation had much to fear themselves. Fear of discrimination and harassment and of being sent off to die in a war. Leonard Wolf wrote in "Voices from the Love Generation" a book that contains interviews of fifteen hippies:

"So many young people have made us suddenly sick. Nowhere are the symptoms of our disease more terrible than in the continuing harsh treatment we give them. My generation has declared war on youth. If they believe in our system we send them to Vietnam as sacrifices to our bad judgment. If they are uncomfortable with our world and act on their discomfort we jail them. Los Angeles Police Chief Parker's solution for Watts was 'arrest, arrest, arrest.' If we arrest enough of our children, the generation gap may finally be visible. Parents will be on one side of the bars, their children on the other."10

The 1960s saw a generation of young people come to be linked historically to trends of rebelliousness. The exceptional combination of social, political, and cultural upheaval in a single decade helped to push the generation into such a heightened state of rebellion. Through the symbol of long hair and other fashion statements, the youth of America expressed who they were and for what they were fighting. The long-haired boys were either seen as drug-using, free-loving hippies or effeminate homosexuals. In the majority of the cases they were neither. They were simply young men taking on a symbol of their youth. "But perhaps the revolt of the 1960s had achieved a greater

\footnotetext{
9 John Kifner, "Lottery Ordered in Illinois Ballot: Court Cites Discrimination in Listing of Candidates," New York Times, 12 August 1969, p. 22.

${ }^{10}$ Joan Cook, "In the 60's, Hair Was a Fighting Word," New York Times, 31 December 1969, p. 29, excerpt from Leonard and Deborah Wolf's Voices From the Love Generation.
} 
victory than the right to wear hair long, a tolerance for the appearance of others, whether their hair was long, short or absent entirely, the dawning of an age when one human no longer snap-judged another by his color, accent, dress, or haircut." ${ }^{\text {11 }}$

Long hair began to represent the dream of a generation. It was dream to live in a world better than the one their parents lived in and better than the one that they were living in at the time. Perhaps John Lennon put it best when he said, "The youth have hope because it's their future that they're hopeful about and if they're depressed about their own future, well, then we are in a bad state. And we keep hope alive by keeping it alive amongst ourselves and I have great hope for the future."12

${ }^{11}$ Severn, "Long and Short," p. 133.

${ }^{12}$ The Beatles, The Beatles Anthology, (Italy: Apple Corps Ltd., 2000), p. 356. 


\section{Bibliography}

\section{Primary Sources:}

\section{$\underline{\text { Report }}$}

Timmins, William. Long Hair in A Merit System: An Appeal From Utopia Avenue. 1972.

\section{Newspapers}

Daily Athenaeum. 1966, 1967, 1968, 1969, 1970, 1971, 1972.

The New York Times. 1966, 1967, 1968, 1969, 1970, 1971, 1972.

The Wall Street Journal. 1966, 1967, 1968, 1969, 1970, 1971, 1972.

\section{$\underline{\text { Articles and Books }}$}

Aron, Raymond. "Student Rebellion: Vision of the Future or Echo From the Past?" Political Science Quarterly 84 (June 1969): 289-310.

Felton, Nadine et al. “A New Generation of Workers.” Liberation 17 (August 1972): 3843.

Golden, Bernice. "New Grooming Aids Invade Men's Market.” Journeyman Barber, Hairdresser, and Cosmotologist 64, February 1968, p. 24-25.

Groves, Mary. "An Open Letter to the Father of a Boy Who Won't Get His Hair Cut." Good Housekeeping, November 1967.

Hester, Philip G., Philip S. Kopala, and Philip Worchel, "Collective Protest and Legitimacy of Authroity." Journal of Conflict Resolution 18, No. 1 (March 1974).

Hood, Victor. "OJT Ends-New Program Under Way." Journeyman Barber, Hairdresser, and Cosmotologist 63, April 1967, p. 4.

Stough,Charles. "Long Hair and Short Tempers: A Case History." School Management, 1974.

Reice, Sylvie. "What Ever Happened To The Hair Controversy?," McCall's, December 1968.

“Case of the Bearded Teacher." Today's Education, May 1970, p. 26. 
“Courts and Long Hair.” Senior Scholastic, 26 April 1971, p. 6.

"Cut Your Hair Boy.” Georgia Straight, 21 May 1971, p. 9.

“Dress Codes Fought.” Fifth Estate, 29 September 1971, p. 10.

"International News." Journeyman Barber, Hairdresser, and Cosmotologist 64, February 1968 , p. 38.

"Fighting Repression South City Schools." Vencermos, 1April 1971, p. 20.

"Good Housekeeping Poll: Have Schools the Right To Enforce Haircuts?" Good Housekeeping, September 1968, p. 12.

"Hair." Newsweek, 5 October 1970, p. 79.

"Hair Do's and Don'ts: Faculty-Student Squabbles Over Hair and Dress Style." Newsweek, 3 October 1966, p. 94.

“Hairy Victory; Court Decision.” Time, 15 June 1970, p. 61.

"High School Hair Regulations." Valprasio University Law, Spring 1970, p. 400.

"Keep This Under Your Hat: The Long-Haired Hard Hat." Newsweek, 26 July 1971, p. 30.

“Long Hair Controversy.” America, 12 November 1966, p. 578.

"Longer Hair Is Not Necessarily Hippie: Time Essay.” Time, 27 October 1967, p. 46.

"Long and Short of It: Sideburns and Miniskirts." Newsweek, 29 September 1969, p. 77.

"Long May It Wave: Long-Hair-For-Boys Issue in Schools." PTA Magazine, December 1969, p. 14.

"Longhairs Fight Back." Great Speckled Bird, 6 September 1971, p. 6.

"Marietta Long Hairs." Great Speckled Bird, 20 September 1971, p. 4.

"Principal Fined for Hair Expulsion." College Press Service, 20 April 1971, p. 4.

“Student's Fight Dress Code.” Militant 14, 9 April 1971. 
"The Trend to Longer Styled Hair Is an Outgrowth of Butch and Crew." Journeyman Barber, Hairdresser, and Cosmotologist 63, March 1967, p. 27.

\section{Secondary Sources:}

\section{$\underline{\text { Articles }}$}

Bindas, Kenneth J., and Heineman, Kenneth J. "Image Is Everything? Televisions and the Counterculture Message in the " 60 s." Journal of Popular Film and Television 22 (1994): 22-37.

Bresler, Robert J. "The Death of Hollywood's Golden Age and the Changing American Character." USA Today Magazine (March 1997, Vol. 125 Issue 2622): 64-67.

Cagin, Seth and Philip Dray. Born to be Wild: Hollywood and the Sixties Generation. Boca Raton, Fl: Coyote, 1994.

Cohen, Ronald D. "The Delinquents: Censorship and Youth Culture in Recent U.S. History." History of Education Quarterly 37 (Autumn, 1997): 251-270.

Graham, Gael "Flaunting the Freak Flag: Karr v. Schmidt and the Great Hair Debate in American High Schools, 1965-1975." Journal of American History (September 2004): 522-543.

Hausman, Ken. "Pioneering Psychiatrist, Psychoanalyst Judd Marmor Dies at Age 93." Psychiatric News (6 February 2004): 2.

James, David E. "Rock and Roll in Representations of the Invasion of Vietnam." Representations 29 (Winter 1990): 78-98.

\section{$\underline{\text { Books }}$}

Appy, Christian. Working-Class War: American Combat Soldiers and Vietnam. University of North Carolina Press: Chapel Hill, N.C., 1993.

Aronowitz, Stanley. False Promises: The Shaping of the American Working Class Consciousness. New York: MacGraw-Hill, 1974.

Cavallo, Dominick. A Fiction of the Past: The Sixties in American History. New York: Palgrave, 1999.

Corson, Richard, and Cox, Caroline. Fashions in Hair: The First Five Thousand Years. London, 2001. 
Esler, Anthony. Bombs Beards and Barricades: 150 Years of Youth in Revolt. New York: Stein and Day Publishers, 1971.

Fass, Paula S. The Damned and the Beautiful: American Youth in the 1920s. New York: Oxford University Press, 1977.

Foley, Michael S.. Confronting the War Machine: Draft Resistance During the Vietnam War. The University of North Carolina Press, 2003.

Garson, Barbara. All the Livelong Day: The Meaning and Demeaning of Routine Work. New York: 1975.

Green, James R. The World of the Worker: Labor in Twentieth-Century America. New York: Hill and Wang, 1998.

Hollingsworth, Ellen Jane, Henry S. Lufler, Jr., William H. Clune III. School Discipline: Order and Autonomy. New York, 1984.

Jeffreys-Jones, Rhodri. Peace Now! American Society and the Ending of the Vietnam War. Yale University Press, 1999.

Jolly, Penny Howell, and Erchak, Gerald Michael. Hair: Untangling A Social History. Saratoga Springs, 2004.

Jones, Landon. Great Expectations: America and the Baby Boom Generation. Coward, McCann, and Geoghegan: New York, 1980.

Lembcke, Jerry. The Spitting Image: Myth, Memory, and the Legacy of Vietnam. New York University Press, 1998.

Levy, Peter B. The New Left and Labor in the 1960s. Baltimore, M.D.: University of Illinois Press, 1994.

McWilliams, John C. The 1960s Cultural Revolution. Westport, C.T.: Greenwood Press, 2000.

Moody, Kim. An Injury to All: The Decline of American Unionism. London: Verso, 1988.

Moser, Richard. The New Winter Soldiers: GI and Veteran Dissent During the Vietnam Era. Rutgers University Press, 1996.

Sann, Paul. American Panorama. New York, 1988.

Severn, Bill. The Long and Short of It: Five Thousand Years of Fun and Fury over Hair. New York, 1971. 
Small, Melvin Antiwarriors: The Vietnam War and the Battle for America's Hearts and Minds. Wilmington: A Scholarly Resources Inc, 2002.

Small, Melvin. Covering Dissent: The Media and the Anti-Vietnam War Movement. New Brunswick: Rutgers University Press, 1994.

Spann,Edward K. Democracy's Children: The Young Rebels of the 1960s and the Power of Ideals. A Scholarly Resources, Inc.: Wilmington, DE, 2003.

The Beatles. The Beatles Anthology. Italy: Apple Corps Ltd., 2000.

The Bible.

\section{$\underline{\text { Movies }}$}

Easy Rider. dir. Dennis Hopper. Metro-Goldwyn-Mayer (MGM) Present a Florin Production, (Universal City, CA: MGM, 1969).

Medium Cool. dir. Haskell Wexler. Paramount Pictures presents a H\&J Production, (Universal City, CA: Paramount, 1969).

Who's Afraid of Virginia Woolf. dir. Mike Nichols. Warner Bros. Pictures presents a Chenault Inc. Production, (Universal City, CA: Warner Bros, 1966).

\section{$\underline{\text { Yearbooks }}$}

The Mohigan. Morgantown High School: 1966, 1967, 1970, 1971.

The Little Monticola. University High School: 1967, 1973.

\section{Websites}

Hesske,Steve. "They Dare Not Speak Its Name." http://www.newdemocracyworld.org/War/fragging.htm (11 October 2006).

King, Jason. St. James Encyclopedia of Pop Culture. 2002, $<$ http://www.findarticles.com/p/articles/mi_g1epc/is_tov/ai_2419100553 $>22$ March 2005, s.v. "Hair".

Linder, Doug. "U.S. Supreme Court: Kelley v. Johnson, 425 U.S. 238 (1976).” Exploring Constitutional Law. 2006, $<$ http://www.law.umkc.edu/faculty/projects/ftrials/conlaw/KelleyvJohnson.html $>$ 2006. 
"Schools History." 11 July 2004, < $<$ http://www.schoolshistory.org.uk/> (22 March 2005). 